UNIVERSIDADE DE BRASÍLIA

Centro de Excelência em Turismo

Thaise Coelho Calaça

\title{
SEGURANÇA ALIMENTAR EM EVENTOS
}

Brasília (DF), Dezembro de 2003. 


\section{UNIVERSIDADE DE BRASÍLIA \\ Centro de Excelência em Turismo \\ Thaise Coelho Calaça}

\section{SEGURANÇA ALIMENTAR EM EVENTOS}

Monografia apresentada ao Curso de Pós-
graduação do Centro de Excelência em
Turismo - UNB, como requisito à
obtenção do título de Especialização em
Gestão da Hospitalidade.

Orientadora: Wilma Araújo

Brasília (DF), Dezembro de 2003. 
Agradeço a Deus, por me abençoar no desempenho da profissão que escolhi. Aos meus pais, por não pouparem esforços para que eu pudesse realizar meus desejos, pelo apoio de todas as pessoas que amo e que me deram força para que eu pudesse superar a saudade, as dificuldades e conquistar mais essa valiosa etapa da minha vida. 


\section{RESUMO}

Tendo em vista a tendência de versatilidade, profissionalismo e crescimento do setor de eventos, e nos investimentos feitos na área com base na proposta de servir alimentos e bebidas nos mais diferentes ou inusitados locais, surge a preocupação com a segurança alimentar, já que em muitos casos não há uma estrutura funcional que assegure seus aspectos fundamentais além de estarem envolvidos profissionais que não têm suas rotinas focadas no preparo de alimentos, mas que ainda assim os manipulam, armazenam ou transportam.

Este trabalho pretende fazer uma reflexão sobre a segurança alimentar e a qualidade dos alimentos em eventos, dando ênfase à importância da capacitação e educação com relação ao serviço dos manipuladores de alimentos, para a qualidade da alimentação servida.

Palavras chave: Eventos, A\&B, Segurança alimentar

\section{SUMMARY}

In view of the trend of versatility, professionalism and growth of the sector of events, and in the investments made in the area on the basics of the proposal to serve foods and drinks in the most different or unusual places, appears the concern with the alimentary security, since in many cases it does not have a functional structure that it assures its basic aspects besides being involved professionals who do not have its routines in the food preparation, but that still thus they manipulate them, they store or they carry.

This work intends to make a reflection on the alimentary security and the quality of foods in events, being given emphasis to the importance of the qualification and education with relation to the service of the food manipulators, for the quality of the served feeding.

Key words: Events, A\&B, alimentary secutity 


\section{SUMÁRIO}

$\begin{array}{ll}\text { 1. Introdução } & 07\end{array}$

$\begin{array}{ll}\text { 1.1. Objetivo Geral } & 08\end{array}$

1.2. Objetivos Específicos 09

1.3. Justificativa 10

2. Eventos, Características e Importância 11

2.1 Alimentos e bebidas em eventos 13

3. Alimentos e Bebidas de acordo com a legislação 13

3.1 Norma 93/43/CEE (União Européia) 14

3.2 Alimentos e bebidas nos empreendimentos da hospitalidade 16

$\begin{array}{ll}\text { 3.3 Doenças transmitidas por alimentos } & 17\end{array}$

4. Segurança Alimentar 19

5. Qualidade sanitária dos alimentos em eventos 21

5.1 Controle em serviços de alimentos 22

5.2 Manipulação dos alimentos $\quad 24$

5.2.1 Perigos presentes nas principais etapas da manipulação de 25 alimentos em eventos

5.3 Estrutura física para serviços de alimentos em eventos 26

5.4 Higiene pessoal para manipuladores de alimentos 28

5.5 Higiene dos Equipamentos e Utensílios 29

5.6 Higiene ambiental para eventos 30

$\begin{array}{ll}\text { 5.6.1 Pisos } & 31\end{array}$

5.6.2 Paredes e azulejos 32

5.6.3 Teto 33

5.6.4 Portas e janelas 33

5.7 Controle de tempo e temperatura dos alimentos 33

5.7.1 Transporte de alimentos em eventos 34

5.7.2 Armazenamento de alimentos em eventos 35

$\begin{array}{ll}\text { 5.7.3 Distribuição de alimentos em eventos } & 37\end{array}$

6. As Boas Práticas de Fabricação como ferramenta para monitorar a 37 qualidade dos alimentos

7. O Sistema APPCC 
8. Considerações Finais 39

9. Referências Bibliográficas 40

10. Anexos 41

Anexo I - Regulamento Técnico de Procedimentos Operacionais 42

Padronizados Aplicados aos Estabelecimentos Produtores /

Industrializadores de Alimentos.

Anexo II - Lista de Verificação das Boas Práticas de Fabricação em

Estabelecimentos Produtores / Industrializadores de Alimentos.

Anexo III - Resolução - EDC n² 275, de 21 de outubro de 2002.

Anexo IV - Portaria SVS/MS n³26, de 30 de julho de 1997.

Anexo V - Portaria CVS-6/99 10/03/99 Doesp 12/03/99 - Regulamento 71

Técnico sobre os Parâmetros e Critérios para o Controle Higiênico-

Sanitário em Estabelecimentos de Alimentos. 


\section{INTRODUÇÃO}

A crescente importância do segmento de eventos, têm representado disseminação de idéias, geração de empregos, investimentos em infraestrutura, e principalmente, a contribuição em reduzir a sazonalidade do trade turístico, além de fazer com que todos os segmentos que dão suporte aos eventos busquem a profissionalização e a melhoria dos serviços prestados.

Tendo em vista a tendência de versatilidade no setor de eventos, e da proposta de servir alimentos e bebidas nos mais diferentes ou inusitados locais, que vão desde fazendas, clubes e salões com precárias estruturas de apoio, até centros de convenções e hotéis que contam com espaços planejados para atender eventos, mas que ainda assim podem ser surpreendidos com utilização de locais distantes ou sem a estrutura fixa de cozinha, surge a preocupação com a segurança alimentar, já que estão envolvidos profissionais que não têm suas rotinas focadas no preparo de alimentos, mas que ainda assim os manipulam, armazenam ou transportam.

E assim, mesmo que todos os cozinheiros ou manipuladores da cozinha estejam preparados para exercerem tal função e conheçam os procedimentos de controle para garantir que o alimento saia de suas mãos pronto para o consumo, este pode passar por outras etapas fora da cozinha, com profissionais de outras áreas que podem não estar preparados para terem contato com o alimento, e expor o mesmo a condições de contaminação até chegar ao consumidor.

Ao promover ou realizar um evento que envolve a oferta de alimentos a finalidade não deve ser de somente alimentar os convidados, mas sim de bem alimentar os convidados. E este serviço não consiste em somente oferecer uma comida bem apresentável e gostosa, mas também um alimento seguro do ponto de vista higiênico.

O objetivo deste trabalho é fornecer subsídios para que organizadores e auxiliares de eventos, maitres, garçons, pessoal responsável pela higienização dos materiais, etc, estejam preparados para levar este alimento até o cliente com segurança. Quando este consome um alimento contaminado, toda a equipe é prejudicada, e o evento, que envolveu tantos outros detalhes e profissionais, é todo prejudicado. Toda a equipe deve 
portanto ser responsável pelos processos que o alimento percorre. E estes processos devem ser muito bem controlados para evitar os altos custos de se detectar uma falha no produto pronto ou na reclamação do cliente.

Evidencia-se portanto, a necessidade de buscar a capacitação desses profissionais através de uma metodologia de trabalho capaz de eliminar tais riscos, oferecendo um controle nas operações de manipulacão, armazenamento e transporte de alimentos em eventos, para desprezar o risco de contaminação. Isto se dará através do desenvolvimento de práticas operacionais referentes às etapas que o alimento atravessa até chegar ao consumidor final, com base nas Boas Práticas de Fabricação e na metodologia APPCC.

As BPF - Boas Práticas de Fabricação propões procedimentos para diminuir, minimizar ou eliminar o impacto dos pontos críticos de manipulação de alimentos.

A metodologia APPCC - Análise dos Perigos e Pontos Críticos de Controle é o mais recente conceito de controle higiênico-sanitário em alimentação. Conceito este já adotado pelo Ministério da Saúde, Portaria ${ }^{\circ}$ 1.428 de 26.11.93, para através dele, avaliar a eficácia e efetividade dos processos, meios e instalações, assim como dos controles utilizados na produção, armazenamento, transporte, distribuição, comercialização e consumo de alimentos de forma a proteger a saúde do consumidor.

\subsection{Objetivo Geral}

Preparar os profissionais envolvidos com atividades de alimentos e bebidas em eventos, proporcionando subsídios para que eles possam conhecer melhor o combate à contaminação através do conhecimento de como, onde e porque ocorre a contaminação.

\subsection{Objetivos Específicos}

- Identificar os pontos críticos de controle da segurança alimentar em eventos;

- Informar padrões de higiene para manipuladores de alimentos; 
- Estabelecer condições operacionais favoráveis para a oferta de alimentos em eventos

\subsection{Justificativa}

A palavra evento em muitos dicionários é definida como um acontecimento, um fato, uma ocorrência. BRITO \& FONTES (2002:14) até descreve de forma mais abrangente:

"evento representa muito mais que um acontecimento de sucesso, uma festa, uma linguagem de comunicação, uma atividade de relações públicas ou mesmo uma estratégia de marketing, o evento é uma soma de esforços e ações planejadas com o objetivo de alcançar resultados definidos junto ao seu público alvo".

A indústria de eventos pode trazer benefícios tanto para os âmbitos comerciais, quanto para os sociais e governamentais. Segundo MARTINS (2003:147), "a movimentação que esse segmento provoca na economia em geral pode desencadear um expressivo e contínuo processo de desenvolvimento econômico".

A comercialização de A\&B em estabelecimentos de hospitalidade é muitas vezes capaz de superar os próprios gastos com hospedagem desde que seja bem administrado. E eventos representa uma excelente ferramenta de venda de alimentos e bebidas.

Um único dia de um turista em uma cidade, paticipando de um evento, gera uma diária de hospedagem e mais no mínimo três refeições, custeados por ele ou pelo evento, sem contar o consumo de água e café, que representa uma grande fatia da receita do setor de $A \& B$ de um hotel, por exemplo.

"A gastronomia representa hoje 30 a 40\% da receita bruta do setor de hospitalidade. Em 1995 haviam 58.886 restaurantes que dispunham de 3,54 milhões de lugares e geravam em torno de 600 mil empregos. Atualmente o segmento emprega mais de 9 milhões de pessoas. A projeção para 2005 é de 11 milhões de empregos." KINTON (et al.:1999)

Um evento caracteriza-se por uma reunião de pessoas por um determinado período de tempo, quase sempre com a oferta de alimentos e 
bebidas, que muitas vezes não acontece em condições higiênico-sanitárias e de infra-estrutura adequada para garantir a segurança alimentar.

"O estabelecimento deve estar localizado, ser construído e mantido de acordo com princípios de projeto sanitário. Deve haver um fluxo linear de produtos e controle de tráfego para minimizar a contaminação cruzada de produtos crus com cozidos e de áreas sujas com áreas limpas" OMS (2001:31).

Segundo a Organização Mundial de Saúde, a higiene dos alimentos compreende "todas as medidas necessárias para garantir a inocuidade sanitária dos alimentos, mantendo as qualidades que Ihes são próprias e com especial atenção para o conteúdo nutricional".

"Todos os funcionários ou quaisquer outras pessoas que entrarem em uma planta de processamento de alimentos devem cumprir os requisitos referentes à higiene pessoal, aos procedimentos de limpeza e sanitização, à segurança pessoal, e devem conhecer seu papel no programa APPCC. As empresas devem manter registros das atividades de treinamento dos funcionários e colaboradores". OMS (2001:31)

\section{Eventos, Características e Importância}

"Um evento pode ser entendido como sendo um acontecimento, previamente planejado, visando atingir resultados definidos junto ao seu público-alvo". CASTELLI (2001:589)

Existem diversos tipos de desses acontecimentos, cada um deles com suas particularidades, ou seja:

- Palestra: apresentação de um tema específico para um grupo de pessoas que, sob a coordenação de um moderador, pode fazer perguntas ao palestrante;

- Seminário: reunião de um grupo de pessoas com um certo nível de conhecimento e experiência em um determinado campo técnico para receber instrução mais avançada sobre aspectos pertinentes à sua profissão ou para debater um tema;

- Mesa redonda: apresentação de pontos de vista (com tempo limitado), sobre um determinado tema, por parte de um grupo de especialistas, com debate entre si e sob a coordenação de um moderador; 
- Simpósio: Reunião de cientistas ou técnicos para expor um determinado assunto, com a participação do público, através de perguntas;

- Painel: Reunião em que especialistas apresentam seus pontos de vista sobre um tema a um grupo de expectadores;

- Fórum: Reunião conduzida por um coordenador, em que os participantes expõem livremente seus pontos de vista sobre um determinado tema, com o objetivo de se chegar a um consenso;

- Congresso: Reunião de um número considerável de participantes, promovida por entidades associativas, para deliberarem sobre assuntos de seu interesse comum. Num congresso pode-se fazer uso de mesas redondas, sessões plenárias, reunião de comissões etc., com o objetivo de apresentar ou discutir assuntos relativos aos propósitos do evento. Além disto, faz parte de um congresso a programação social, incluindo almoços, jantares, coquetéis e homenagens;

- Convenção: Reunião política com o objetivo de escolher candidatos ou tomar decisões. Pode ser entendida também como uma reunião de grande importância promovida por entidades empresariais;

- Conferência: Reunião de um grupo de pessoas para debater um assunto exposto pelo conferencista;

- Conclave: Reunião de caráter religioso com o objetivo de debater assuntos ligados à religião;

- Exposições: Reunião de pessoas para expor produtos, sem a venda dos mesmos;

- Feiras: Reunião de pessoas para expor e vender produtos;

- Concurso: Reunião de pessoas com o objetivo de disputar uma competição regida por um regulamento específico;

- Entrevista coletiva: Reunião entre uma personalidade e imprensa para esclarecimentos e questionamentos;

- Leilão: Reunião de pessoas com o objetivo de comprar algo, sob um comando de um leiloeiro;

Assim como almoços, jantares e coquetéis são muito parecidos do ponto de vista gastronômico, todos os tipos de eventos acima citados têm um grande ponto em comum, a inserção de alimentos e bebidas como forma de 
atrair, descontrair, ou de simplesmente promover um intervalo entre os debates.

A maioria dos eventos acima citados, acontecem durante um dia inteiro ou até mesmo uma semana inteira em um mesmo local. Costumeiramente contam com intervalos breves onde os participantes, que estão longe de suas casas, aproveitam para alimentar-se. E para que este participante não tenha que se ausentar por muito tempo a procura de alimento, e acabar-se dispersando, a própria organização do evento procura promover estes intervalos com oferta de alimentação no próprio local da reunião, sem custo direto para o participante.

Estas ofertas podem ser desde um coffee break rápido com bebidas do tipo café, água, chá, suco e refrigerante e alimentos como petit fours, quitandas, mini sanduíches e frutas, enfim produtos com uma resistência maior ao tempo de exposição e que oferecem menores riscos de toxinfecções alimentares, como até mesmo almoços, onde o promotor do evento ofereça um curto intervalo de tempo e tenha interesse de que seus participantes se alimentem todos no local da reunião ou jantares e coquetéis, que além de proporcionar um momento de confraternização, pode significar também uma lembrança inesquecível do evento.

O "turismo de eventos" é um dos segmentos do turismo que mais cresce no Brasil e no Mundo. Segundo Caio L. de Carvalho no artigo "Turismo em análise", vários são os benefícios trazidos pelo turismo de eventos para a cidade-sede e para o país, tais como: redução dos problemas de sazonalidade; entrada de divisas para o país / cidade; geração imediata de emprego e renda; mobilização do trade turístico; divulgação da imagem do local sede do evento; mobilização dos prestadores de serviço, que vão desde floriculturas, fornecedores de equipamentos a mão de obra especializada do tipo seguranças e recepcionistas.

\subsection{Alimentos e bebidas em eventos}

Dentre os diversos tipos de eventos, os que estão mais intimamente ligados à prestação de serviços de alimentos e bebidas são os banquetes. Que é caracterizado por ser uma refeição (almoço ou jantar) solene ou festiva 
em que um grupo de pessoas se reúnem para celebrar um acontecimento marcante da vida social ou política. Nesta ocasião serve-se um mesmo menu a todas as pessoas dispostas em uma mesma mesa ou em mesas grandes, próximas umas das outras.

Quando as pessoas se reúnem para uma refeição, de caráter solene e festivo, a designação mais adequada é café da manhã, almoço, jantar, coquetel, etc. Contudo, todas essas manifestações podem ser inseridas dentro da designação de eventos.

Um caso muito especial é o da alimentação coletiva destinada a participantes de grandes eventos, como olimpíadas, exposições universais, peregrinações, visitas de pessoas muito importantes como o Papa, etc. Nestas ocasiões em que se preparam alimentos em quantidades surpreendentes, fora do comum, há maiores possibilidades de que a qualidade dos alimentos se altere, ou de que ocorram surtos das doenças transmitidas pelos alimentos. A aplicação das metodologias citadas neste trabalho permitirão o sucesso deste e de todos os outros tipos de eventos no que tange a segurança alimentar.

\section{Alimentos e Bebidas de acordo com a legislação}

Na prestação de serviços de alimentação coletiva é necessário dispor e aplicar regulamentações oficiais e/ou privadas que rejam e controlem as ações diárias, e que sirvam como marco legal, jurídico e que estabeleça responsabilidades, direitos e deveres. A meta de todo estabelecimento de alimentação coletiva é, ou deveria ser, oferecer aos seus clientes ou comensais, alimentos inócuos e de excelente qualidade, em um ambiente adequado e com o melhor serviço e atenção.

Os governos nacionais, estaduais, municipais; os organismos internacionais relacionados, as associações de hotelaria e alimentação, nacionais ou internacionais, têm os mesmos objetivos e se esforçam por preparar e fazer cumprir leis, regulamentos, normas, diretrizes, especificações e padrões que permitam atingir os objetivos assinalados.

A cada dia os consumidores tornam-se mais esclarecidos e exigentes quanto à qualidade dos produtos que adquirem. No âmbito do governo, a 
legislação e a fiscalização dos alimentos e bebidas industrializados vem adotando critérios cada vez mais rigorosos.

De acordo com a legislação vigente, todos os estabelecimentos que industrializam, comercializam, distribuem e prestam serviços na área de alimentos devem possuir um sistema de garantia de qualidade, através da adoção de Boas Práticas de Fabricação (BPF) e da Análise de Perigos e Pontos Críticos de Controle (APPCC). Ambas dão sustentação à implantação posterior da série ISO 9000.

Existem regulamentações ou mecanismos locais para todos e cada um dos aspectos relacionados com a indústria e comércio da alimentação coletiva. A construção e adequação dos locais, as matérias-primas, os serviços sanitários, os funcionários, as operações de manipulação, conservação, processamento e preparação dos alimentos, recebem a devida atenção nos instrumentos legais. Todo estabelecimento deveria possuir, e colocar ao alcance dos trabalhadores, exemplares da legislação local e nacional, com a finalidade de que as conheçam e as cumpram, para não alegar depois seu desconhecimento, ao tentar justificar erros cometidos que possam desencadear, por exemplo, um surto epidêmico de uma doença transmitida por alimentos.

Dentro das regulamentações que estão relacionadas com as boas práticas de manufatura ou práticas corretas de fabricação, os códigos de higiene, etc. Um excelente documento geral é o Código Internacional de Práticas. Princípios Gerais de Higiene dos Alimentos, preparado e aprovado pelo Codex Alimentarius da OMS e FAO.

\subsection{Norma 93/43/CEE (União Européia)}

A Norma apresenta um Anexo que mostra, nos seus respectivos capítulos, diversos aspectos que devem ser cumpridos. Por exemplo, o Capítulo I se ocupa dos "Requisitos gerais para os locais de empresas alimentícias".

- "Os locais por onde circulam produtos alimentícios deverão estar limpos e em bom estado; 
- A disposição do conjunto, o projeto, a construção e as dimensões dos locais por onde circulam os produtos alimentícios deverão:

- Permitir uma limpeza e desinfecção adequadas;

- Evitar o acúmulo de sujeira, o contato com materiais tóxicos, o depósito de partículas e a formação de condensação ou mofo indesejável nas superfícies;

- Possibilitar as práticas corretas de higiene dos alimentos, inclusive durante as diferentes operações, a prevenção da contaminação cruzada provocada pelos alimentos, o equipamento, os materiais, a água, a provisão do ar, os funcionários ou fontes externas de contaminação tais como insetos e outros animais;

- Oferecer quando for necessário, as condições técnicas adequadas para o tratamento e a armazenagem higiênica dos produtos.

- Deverá existir um número suficiente de lavabos, devidamente localizados e sinalizados, para a limpeza das mãos, assim como de vasos sanitários com as descargas conectadas a um sistema de esgoto eficaz. Os vasos sanitários não devem comunicar-se diretamente com os locais onde se manipulam alimentos;

- Os lavabos para a higiene das mãos devem possuir água corrente fria e quente, assim como material para a limpeza e secagem higiênica das mãos. Quando for necessário, as instalações para lavar os produtos alimentícios devem estar separadas das instalações destinadas à lavagem das mãos;

- É necessário contar com meios apropriados e suficientes de ventilação mecânica ou natural. Evitar toda corrente de ar mecânica de uma área contaminada para outra limpa. Os sistemas de ventilação deverão estar construídos de forma que se possa ter acesso fácil aos filtros e outras partes que devam ser limpas ou construídas;

- Todos os serviços sanitários instalados nos locais onde circulem os produtos alimentícios deverão dispor de ventilação adequada, natural ou mecânica;

- Os locais por onde circulam os produtos deverão estar suficientemente iluminados por meios naturais ou artificiais;

- Os sistemas de esgoto deverão ser os adequados para os objetivos previstos e na sua construção e projeto dever-se-á ter evitado qualquer risco de contaminação dos produtos alimentícios; 
- Onde for necessário, deverão existir vestiários suficientes para o pessoal da empresa;

- Se necessário se disporá de instalações próprias para a limpeza de desinfecção dos instrumentos e materiais de trabalho. Estas instalações deverão ser construídas com um material resistente à corrosão, fáceis de limpar e ter uma provisão adequada de água fria e quente;

- Se for o caso, serão tomadas as medidas adequadas para a lavagem dos alimentos. Todas as pias ou as instalações similares destinadas à lavagem de alimentos deverão ter uma provisão adequada de água potável quente, fria ou ambas, segundo a necessidade, e devem manterse limpas". OMT (2003:131)

\subsection{Alimentos e bebidas nos empreendimentos da hospitalidade}

O departamento de alimentos e bebidas de um hotel, pode ser considerado hoje, como um dos mais complexos de toda a estrutura. Em um hotel de grande porte, este departamento pode oferecer diversas opções de restaurantes, desde lugares mais econômicos como coffee shops e restaurantes voltados para famílias, até restaurantes caros e safisticados, especializados em haute cuisine, com um serviço impecável. Mais ainda, o departamento pode operar em salões, happy hours, shows noturnos; banquetes, eventos, chás e serviços de buffet; room service e bares.

Observa-se portanto que qualquer tipo de serviço de alimentação pode ser encontrado nos estabelecimentos de hospedagem. Examinando mais detalhadamente este mercado pode-se ressaltar que os mesmos princípios que regem um serviço eficiente de $A \& B$ se aplicam, também, a outras operações comerciais que fazem parte do setor de alimentação, como instituições beneficentes, redes de fast food, restaurantes independentes, hospitais, universidades, etc.

Muitos hotéis oferecem, entre suas facilidades, banquetes e recepções para grupos pequenos ou grandes. Esses serviços podem ser oferecidos pelo próprio hotel (ex., buffet no dia das mães), mas mais frequentemente, são requisitados por aqueles que precisam dos serviços, seja para a família, seja para os negócios. 
Pode ser um serviço informal, como um happy hour à beira da piscina para pessoas que estejam participando de uma conferência, ou muito elegante como um jantar de gala. Os banquetes e recepções podem ainda se caracterizar por serviço de mesa, serviço de buffet ou uma combinação dos dois. Praticamente todos os tipos de serviços oferecidos em uma operação de restaurante são também viáveis em uma operação de banquetes.

Quer essa operação de alimentos seja em um hotel, restaurante independente, ou instituição, ela requer os serviços de um profissional qualificado para avaliar os desejos, necessidades e expectativas da clientela e fazer com que sejam realizados. Como existem mais similaridades do que diferenças nas operações de alimentos dos hotéis, restaurantes e instituições, as discussões sobre gerenciamento e suas regras também se aplicam aos diversos tipos de operações de alimentos.

\subsection{Doenças transmitidas por alimentos}

Os principais fatores que contribuem para surtos de doenças de origem alimentar são: temperatura inadequada de armazenagem, tempo e temperatura de cozimentos incorretos, matéria prima de qualidade insatisfatória, equipamentos, utensílios contaminados e más condições higiênicas dos manipuladores.

Além disto, o preparo de alimentos com muita antecedência ao momento de servir, a falta de condições adequadas de armazenagem, a contaminação cruzada, a adição de alimentos contaminados a alimentos já cozidos sem reaquecimento suficiente e o reaproveitamento de alimentos podem contribuir para o aparecimento de surtos.

Para combater a ocorrência de doenças causadas por alimentos, a legislação brasileira prevê que, em estabelecimentos produtores de alimentos, existem certos procedimentos de Boas Práticas que devem ser enfatizados como prioridade para que se possa fornecer produtos de qualidade. Estes procedimentos incluem: localização, estrutura da área de manipulação, abastecimento de água, lixo, higienização de equipamentos, utensílios e ambiente, seleção de matéria-prima, manipuladores, controle de insetos e roedores e informações ao consumidor. 
As espécies ou grupos de microorganismos predominantes no alimento irá depender das características do alimento, da qualidade da água, da composição do alimento, bem como das condições ambientais.

Uma enfermidade transmitida por Alimentos (ETA) ocorre quando se ingere um alimento (ou água) que possui uma quantidade suficiente de um elemento perigoso. O conceito de quantidade suficiente é específico para cada perigo em particular. No caso de perigos biológicos essa "quantidade" é conhecida como dose infectante mínima.

As ETA de origem biológica podem ser classificadas em: infecções e intoxicações. Uma infecção ocorre quando uma toxina, ou veneno fabricado por bactérias, algas ou fungos, está presente no alimento ingerido provocando uma doença no consumidor. Também alguns tecidos animais ou vegetais podem causar intoxicações.

As ETA de origem química são conhecidas, geralmente, como intoxicações ou envenenamentos. Os perigos químicos podem, também, ocasionar males crônicos ou alergias.

- Toxinfecções de origem alimentar - Doenças causadas pela ingestão de alimento contaminado por micoorganismos patogênicos que se multiplicam, podendo invadir a parede intestinal e disseminar-se para outros órgãos, caracterizando uma infecção.

- Intoxicação por Intoxicação por enterotoxina estafilocócica - É a doença de origem alimentar mais comum e resulta da ingestão de alimentos contaminados com a toxina produzida por Staphylococcus aureus, que é extremamente resistente. A bactéria é geralmente transmitida pelas mãos, fato que faz dos manipuladores de alimentos as fontes de contaminação mais frequentes.

- Intoxicação por neurotoxina botulínica - A palavra botulinum vem do latim, botulus, que significa salsicha. A doença chama-se botulismo porque os primeiros casos ocorreram com pessoas que haviam se alimentado de salsichas (botulus) contaminadas. Isso ocorreu na Bélgica, em 1896.

A maior causa de surtos de botulismo tem sido a ingestão de alimentos conservados ou semi-conservados em latas, vidros ou produtos curados, dos quais o oxigênio tenha sido removido. Outros surtos descritos apontam a 
preservação artesanal imperfeita e alimentos não ácidos, queijos, peixes, cogumelos e palmitos enlatados.

- Toxinfecção por clostridium perfringens - o clostridium perfringens é uma bactéria largamente encontrada na natureza. É comum no solo e em terrenos encharcados, e ainda em vegetais. Produz uma toxina no intestino quando são ingeridos alimentos contaminados pela bactéria em sua forma vegetativa. Os produtos que contém carne bovina ou de aves, geralmente com molhos mantidos em temperatura ambiente, são os principais alimentos em que há proliferação dessa bactéria. A mortalidade é baixa e atinge principalmente crianças e pessoas idosas ou debilitadas. Não existe tratamento específico.

- Infecções por Salmonella - algumas espécies de salmonella podem produzir dois tipos de doenças de origem alimentar. As gastroenterites, caracterizadas por infecção no intestino, e as febres entéricas, que são mais graves e conhecidas como febres tifo, constituindo infecções generalizadas.

$\mathrm{Na}$ gastroenterite, os principais alimentos propícios ao crescimento da bactéria Salmonella são os produtos de confeitaria, maionese, produtos de ovos e as carnes e derivados. Os sintomas típicos são dores abdominais, calafrios e prostração, e o tratamento é feito à base de hidratação e uso de antibióticos.

Já nos casos de febre tifóide, verifica-se que o leite, ou os alimentos contaminados com dejetos de portadores humanos de febre tifóide, além da água contaminada por esgoto são as causas desse tipo de infecção. Pode ser fatal. O tratamento é feito com hidratação e antibióticos.

- Outras doenças de origem microbiana - os sintomas clássicos das doenças de origem microbiana transmitidas por alimentos são sinais próprios de distúrbios gastrointestinais agudos, como diarréia ou vômito, associados a dores abdominais e desconforto. Outros micoorganismos também são importantes patógenos. Além de bolores formadores de toxinas, vírus e protozoários, outras bactérias veiculadas por alimentos podem provocar doenças: Shigella; Campylobacter spp; E. coli (patogênicas); Yersínia enterocolítica; vibrio parahaemolyticus; Vibrio choleae; Aeromonas; Plesxiomonas shigelloides; Bacillus cereus e Listeria monocytogenes. 


\section{Segurança Alimentar}

Entende-se por segurança alimentar a aquisição, pelo consumidor, de alimentos de boa qualidade, livre de contaminantes de natureza química, biológica, física ou quaisquer substâncias que causem danos à saúde. Garantir a segurança alimentar exige aplicar sistemas que monitorem a qualidade dos produtos nas etapas operacionais que vão desde a recepção e armazenamento dos produtos até a manipulação e distribuição do alimento preparado.

"Segundo a Organização Mundial de Saúde - OMS e informações recentes sobre doenças de origem alimentar no Brasil, verifica-se que mais de $60 \%$ são toxinfecções alimentares, cujos agentes etiológicos estão entre bactérias, vírus, fungos e parasitas". SILVA JR. (2002).

$\mathrm{Na}$ área de alimentos, qualidade é essencialmente a inocuidade. E o sistema mais aceito e de melhor resposta para obtenção de produtos inócuos para monitoramento desta qualidade é o de Boas Práticas de Fabricação (BPF), que representa recomendações que devem ser adotadas pelas unidades de produção de alimentos.

Em suas diversas etapas de produção, os alimentos estão sujeitos à contaminação por diferentes microorganismos provenientes da manipulação inadequada, contato com equipamentos, superfície e utensílios higienizados e sanificados de forma incorreta, ou provenientes da atmosfera ambiental.

No âmbito da segurança alimentar, três processos devem ser tratados com especial atenção: a higiene, a desinfecção e a limpeza. Geralmente, confunde-se higiene com limpeza, considerando-as sinônimos. Certamente estão intimamente relacionadas, mas não são a mesma coisa.

Higiene é um termo muito mais amplo, e é definida pela Enciclopédia Britânica como "parte das Ciências Médicas que tem por objeto a conservação da saúde de prevenção das doenças".

Limpeza, porém é "a qualidade de limpo, a ação ou efeito de limpar ou limpar-se". A limpeza é um procedimento que separa, suspende ou dissolve, geralmente em água. A efetividade da limpeza pode ser otimizada através de meios mecânicos ou químicos. A limpeza, para que seja realmente efetiva, deve realizar-se com muita frequência para eliminar os resíduos de 
alimentos, a acumulação de gordura, os depósitos minerais, o pó e qualquer outro tipo de sujeira que possa alimentar os microorganismos ou protegê-los. Uma limpeza bem realizada não é necessariamente o resultado da simples conjunção de água, sabão e força muscular. Deve haver uma combinação de força mecânica, produto químico, tempo de contato e temperatura.

Também confunde-se limpeza com desinfecção, porém esta última se refere à eliminação ou destruição dos microorganismos que podem estar contaminando uma superfície, um equipamento, um utensílio, ou pratos ou talheres, etc. Na prática, o melhor desinfetante é o calor, já que as temperaturas elevadas aplicadas durante um tempo suficientemente prolongado, destruirão a maioria dos microorganismos contaminantes, podendo inclusive chegar à esterilização. É importante ressaltar que nenhum desinfetante deve ser usado para substituir a limpeza profunda de superfícies e utensílios.

\section{Qualidade sanitária dos alimentos em eventos}

Qualidade em eventos pode ser definida, do ponto de vista subjetivo, como a relação entre a expectativa e a realidade, avaliada pela satisfação do cliente. "Qualidade é o conjunto de traços e características de um produto ou serviço para satisfazer as necessidades específicas ou implícitas do consumidor". OMT (2003:1)

Um fator muito importante que deve ser considerado para entender a decisão do cliente ao escolher a empresa que cuidará da alimentação dos participantes de seu evento é a relação qualidade-preço. Mas, também há diversos fatores que incidirão na hora de qualificar um fornecedor e os serviços que oferece, como de excelente qualidade, de boa qualidade, ou sem nenhuma qualidade.

"A qualidade se obtêm quando a expectativa do cliente antes da venda do produto coincide com a percepção que ele tem do mesmo depois da venda, ou bem quando a percepção supera ligeiramente a expectativa... se o serviço resultante excede positivamente as expectativas do cliente pode-se falar em excelência". OMT (2003:2) 
O conceito de qualidade num empreendimento gastronômico, além de estar associado ao serviço oferecido e ao aspecto sensorial - textura, combinação de aromas, cores e sabores; também deve estar associado à questão sanitária, ou segurança alimentar.

\subsection{Controle em serviços de alimentos}

O serviço denominado "Buffet" é muito utilizado em eventos caracterizados pela informalidade, pois os próprios clientes servem-se das iguarias que ficam à sua disposição.

A exposição dos alimentos nesse tipo de serviço pode durar várias horas, principalmente se as porções forem grandes e não houver reposição freqüente das preparações. Para alimentos frios como saladas, antepastos e sobremesas, nem sempre é utilizado balcão frigorífico e os preceitos de tempo I temperatura para cama de gelo devem ser rigorosamente acompanhados. Exemplos:

- Saladas à base de maionese: Sempre devem ir para o bufê em temperaturas abaixo de $4 \mathrm{C}$ e a matéria prima básica deve ser sempre industrializada pois $\mathrm{o} \mathrm{pH}$ dessas maioneses sempre será inferior a 4.0 ao contrário daquelas feitas com ovos in natura.

- Molhos de saladas: Todos os que não forem industrializados devem ter o seu $\mathrm{pH}$ avaliado.

- Folhas, legumes crus e queijos duros: Não oferecem risco em períodos de exposição prolongada.

- Carpaccio, salmão in natura, ostras frescas: devem ter em sua cadeia de preparo todos os aspectos de segurança observados com rigor, incluindo-se o rígido acompanhamento do fornecedor e análises microbiológicas de controle destes produtos. O tempo de exposição não deve ser superior a 30 minutos em temperatura na faixa de risco e porções não consumidas devem ser repostas no bufê por outra e a anterior deve ser desprezada.

- Saladas de grãos, ovos cozidos e legumes cozidos: Observar rigorosamente a temperatura de apresentação no bufê (inferior a $4 \mathrm{C}$ ) e tempo de exposição em temperatura de risco não superior a 30 minutos. 
- Alimentos quentes: Devem estar em rechaud acima de 55C ou sua reposição deve ser freqüente se não houver condições de manutenção à quente e o alimento tiver que permanecer na faixa de risco por mais de 30 minutos. Preparações como sopas, ensopados, cozidos, molhos e outras que tenham na sua composição uma grande quantidade de líquido permanecem em temperaturas superiores a $55 \mathrm{C}$ no rechaud sem qualquer problema, mas bife à milanesa, hamburger, filés à doré, grelhados, entre outros, não tem líquido que transfira o calor do rechaud para eles e mesmo que sejam dispostos nesse serviço com temperaturas superiores a 80C (ou seja, logo após sua fritura), a tendência é de perda gradativa de temperatura, além de que gastronomicamente o aspecto do produto não é agradável, ficando ressequido.

- Sobremesas inteiras ou individuais: Em geral elas devem ir ao buffet com temperaturas o quanto mais próximas de $\mathrm{OC}$, melhor. Caso o tempo de exposição seja superior a 2 horas, as sobras devem ser desprezadas. As outras sobremesas como salada de frutas, creme chantilly cuja contaminação se dá por deteriorantes, quando não estiverem em condições de serem consumidas apresentarão alterações de cheiro e sabor.

- Bufês de café da manhã: Leite frio deve preferencialmente ser do tipo Longa Vida por ser mais estável, podendo ficar exposto por mais tempo que o de saquinho convencional. O uso de recipiente com gelo para manutenção, deve ser considerado; Frutas in natura não apresentam risco de exposição e reaproveitamento após término do serviço; Biscoitos também não apresentam risco de exposição ou aproveitamento; Pães doces e salgados que não tenham recheio não apresentam problema de exposição podendo ser reaproveitados, no entanto, se tiverem creme confeiteiro ou outro recheio, a exposição não deve ser superior a 3 horas, devendo ser desprezadas as sobras; Ovos mexidos, salsichas, lingüiça e bacon frito: devem ficar em rechaud para não atingirem a faixa de risco. Uma opção é servir porções diretamente da cozinha ou fazer a reposição com freqüência; 


\subsection{Manipulação dos alimentos}

Atualmente a qualidade é componente fundamental dos alimentos, como a segurança é também componente indispensável à qualidade, sendo relevante conhecer as variáveis que podem afetar tais componentes dentre os quais a condição higiênico-sanitária dos alimentos que o manipulador interfere diretamente, podendo comprometer a qualidade dos mesmos durante as diferentes fases de elaboração, ainda quando tiverem sido bem sucedidas as fases de produção.

Por outro lado, está amplamente comprovado que a maioria dos casos de toxinfecções alimentares, ocorre devido à contaminação dos alimentos através de manipuladores, seja por hábitos inadequados de higiene pessoal ou, por desconhecimento dos processos que garantem a inocuidade dos alimentos.

A falta de disciplina por parte dos manipuladores também faz com que seja freqüente observar a mais variada e incrível quantidade de más práticas ou hábitos, que atentam contra a qualidade e inocuidade dos alimentos, e desprestigiam os estabelecimentos fornecedores deste tipo de serviço. Entre elas pode-se mencionar:

- Fumar ou mascar chicletes durante a manipulação dos alimentos deve ser totalmente proibido, porque favorece a sua contaminação;

- Também não se deve permitir que se ingiram alimentos durante o trabalho. Os cozinheiros devem utilizar práticas higiênicas para experimentar os alimentos que estão preparando, nunca devem usar para isso as conchas que servem para agregar ingredientes ou para misturar os alimentos, com eles podem extrair uma pequena porção que será colocada em um prato pequeno ou em uma colher para experimentar, depois de usados o prato e a colher devem ser lavados e desinfectados;

- Hábitos aparentemente inofensivos, como colocar as mãos nos bolsos da calça, não são adequados para o manipulador, esse costume favorece a contaminação das mãos e depois, através delas, a dos alimentos com os quais trabalha; uma boa medida, é que as calças do uniforme não tenham bolsos; 
- Cuspir no chão ou nas pias onde se lavam os alimentos, utensílios, pratos e talheres é uma prática desastrosa, porém muitos manipuladores realizam sem perceber suas características anti-higiênicas e antiestéticas;

- Usar os panos de prato para secar o suor ou as mãos, ou para limpar o piso quando derramam algum líquido;

- $\quad$ Tossir ou espirrar perto ou sobre os alimentos, sem tomar medidas para protegê-los;

- Cortar as unhas ou fazer as unhas em áreas destinadas ao manuseio de alimentos;

- Lavar as mãos em pias destinadas à preparação de alimentos;

- Colocar os pratos, ou xícaras, nos que se sirvam alimentos ou bebidas, uns sobre os outros, para poder trasladar um maior número de cada vez;

- Pegar os copos, taças ou xícaras, pela borda ou pelo lado que se leva a boca;

- Segurar os talheres pelo lado que se leva a boca e não pelos respectivos cabos;

- Não usar pinças ou conchas para servir ou mudar de lugar determinados alimentos como pão, cubos de açúcar, etc., usando no seu lugar as mãos.

Dentre as medidas aplicáveis na prevenção de doenças transmitidas por alimentos, a educação e a informação sobre higiene dos alimentos e dos manipuladores devem ser destacadas. Somente através de eficazes e permanentes programas de treinamento, e conscientização dos manipuladores é que se conseguirá produzir e oferecer ao consumo, alimentos seguros, inócuos e com propriedades nutricionais que satisfaçam a um consumidor cada vez mais exigente e informado.

\subsubsection{Perigos presentes nas principais etapas da manipulação de alimentos em eventos}

\begin{tabular}{l|l}
\hline \multicolumn{1}{c|}{ ETAPAS } & \multicolumn{1}{c}{ PERIGOS } \\
\hline Recebimento & $\begin{array}{l}\text { Contaminação pelos utensílios e mãos dos } \\
\text { manipuladores. }\end{array}$ \\
Escolha & Disseminação da contaminação na cozinha. \\
\hline
\end{tabular}




\begin{tabular}{|c|c|}
\hline Lavagem & $\begin{array}{l}\text { Contaminação pelo ambiente, mãos, utensílios, } \\
\text { sobra de sujidades e microorganismos patogênicos, } \\
\text { devido à falta de produtos adequados e técnica } \\
\text { incorreta para higienização dos vegetais. }\end{array}$ \\
\hline Cocção & $\begin{array}{l}\text { Não destrói bactérias esporuladas. Se a temperatura } \\
\text { correta de cocção não for atingida, as bactérias na } \\
\text { forma vegetariana podem sobreviver. }\end{array}$ \\
\hline Refrigeração & $\begin{array}{l}\text { Permite o crescimento das bactérias se o tempo } \\
\text { para atingir a temperatura de segurança for muito } \\
\text { longo. }\end{array}$ \\
\hline Reaquecimento & $\begin{array}{l}\text { Não destrói bactérias esporuladas. Não inativa } \\
\text { toxinas pré-elaboradas. Se não atingir temperatura } \\
\text { adequada, as bactérias na forma vegetativa podem } \\
\text { sobreviver. }\end{array}$ \\
\hline $\begin{array}{l}\text { Espera e } \\
\text { distribuição }\end{array}$ & $\begin{array}{l}\text { Tempo excessivo de espera em temperatura que } \\
\text { favoreça a multiplicação dos microorganismos que } \\
\text { sobreviveram à cocç̧ão, permite atingir contagens } \\
\text { suficientes para causar toxinfecção alimentar. }\end{array}$ \\
\hline $\begin{array}{l}\text { Higiene de } \\
\text { equipamentos e } \\
\text { utensílios }\end{array}$ & $\begin{array}{l}\text { Patógenos nas superfícies de equipamentos e } \\
\text { utensílios de preparação aumentam a contaminação } \\
\text { cruzada. }\end{array}$ \\
\hline Higiene das mãos & $\begin{array}{l}\text { Patógenos nas mãos aumentam o risco de } \\
\text { contaminação cruzada }\end{array}$ \\
\hline
\end{tabular}

\subsection{Estrutura física para serviços de alimentação em eventos}

$\mathrm{Na}$ alimentação em eventos, tratando-se de um estabelecimento pequeno ou grande, o local destinado à cozinha deverá reunir características específicas que o habilitem para a importante função que deve cumprir. $\mathrm{Na}$ realidade, toda cozinha merece, independentemente das suas dimensões uma excelente qualificação, seja qual for a classificação oficial do estabelecimento.

Um dos principais inconvenientes encontrados com frequência é de que muitas vezes os salões de eventos, especialmente os pequenos, se organizam em locais improvisados que necessitam ser adaptados para esta finalidade. Salas ou salões de banquetes mais selecionados não sofrem, 
geralmente, grandes inconvenientes, inclusive às vezes se beneficiam pela beleza ou autenticidade de determinados detalhes da decoração.

Mas é nos espaços destinados às cozinhas onde se apresentam os maiores problemas, que posteriormente vão se refletir na qualidade e, especialmente, na inocuidade dos alimentos que neles são preparados. O importante é que, em qualquer local onde se deseje instalar um local para servir alimentos, todos os ambientes destinados à recepção, armazenamento e preparação dos alimentos sejam construídos especialmente ou reconstruídos adaptando-os tecnicamente para que cumpram adequadamente suas funções.

Esses ambientes devem estar projetados para poder prevenir os perigos microbianos, mas também é necessário considerar a segurança ocupacional - inclusive a prevenção de incêndios - as facilidades que impeçam o movimento desnecessário ou as perdas de tempo por parte do pessoal, e as considerações estéticas que façam mais prazeroso seu trabalho, além de atrair o elogio ou a satisfação dos comensais, e gerar a confiança dos clientes que ocasionalmente possam observar ou visitar esses ambientes.

O projeto higiênico-sanitário desses lugares deve considerar como primeira prioridade as instalações de água potável e as tubulações de esgoto, a existência e locallização das câmaras frigoríficas ou equipamentos de refigeração. Também devem ser considerados, obviamente, os pisos as paredes, os tetos, os depósitos, iluminação e ventilação, os vestiários para os funcionários, os corredores de circulção, etc. OMT (2003:52).

De maneira geral, estes locais não devem oferecer condições ambientais para o acúmulo de matéria orgânica ou umidade, por exemplo rupturas, fissuras, ângulos imprórios, etc., ou o uso de materiais absorventes de difícil limpeza. Todas as superfícies devem ser projetadas de tal forma que sejam fáceis de limpar.

É necessário que o projeto da cozinha permita a separação entre material sujo e material limpo, além de permitir também a separação entre operações "sujas" e "limpas". As áreas frias devem estar separadas da quentes. A ventilação das instalações deve impedir o acúmulo de umidade. As áreas úmidas também devem estar separadas das áreas secas. 
Em todas as ocasiões deve-se evitar o acúmulo de objetos ou equipamentos, mesmo os necessários, ou um número excessivo de pessoas; a aglomeração gera lugares que não são facilmente acessíveis para a limpeza e desinfecção, transformando-os em fontes de contaminação continua. Além disto o acúmulo dificulta ou impede a circulação de produtos e pessoas, diminuindo consideravelmente a produtividade.

Os pisos devem ser projetados e construídos de forma que sejam fáceis de limpar, e que não permitam o acúmulo de substâncias orgânicas, gordura ou umidade. Por isso, é necessário impedir que fendas, rachaduras, rupturas de qualquer tipo permaneçam nos pisos sem que sejam consertadas. O material de construção dos pisos é muito importante, deve-se evitar os materiais que não permitam o uso frequente de detergentes ou de agentes de limpeza similares e desinfetantes. Também por razões de segurança deve-se evitar materiais escorregadios. As uniões entre pisos e paredes devem ser arredondadas, para facilitar a limpeza e desinfecção e evitar o acúmulo de restos orgânicos.

As paredes, especialmente nas áreas onde os alimentos crus ou cozidos são manipulados com maior frequência, devem ter revestimento de materiais não porosos, facilmente laváveis e de cor clara.

As janelas não deveriam existir nas áreas de manuseio dos alimentos de uma cozinha. No caso de existirem, elas devem ter redes metálicas para impedir a entrada de insetos, pássaros e outros animais.

As portas devem fechar o mais hermeticamente possível, para evitar a entrada de pó, de roedores e de insetos. Deve-se evitar as maçanetas ou similares que favoreçam a contaminação cruzada entre os alimentos, ao ser utilizadas pelo pessoal que manipula alimentos crus e pelos que manipulam alimentos já preparados.

A ventilação é um dos fatores-chave para a eficiência e eficácia de uma cozinha. As correntes de circulação de ar podem ser o veículo no qual se espalham os micoorganismos patogênicos.

\subsection{Higiene pessoal para manipuladores de alimentos}

As pessoas que manipulam, armazenam, transportam, processam ou preparam os alimentos são muitas vezes responsáveis por sua 
contaminação. Todo manipulador pode transferir patógenos a qualquer tipo de alimento, mas isso pode ser evitado através da higiene pessoal, comportamento e manipulação adequados.

Os manipuladores de alimentos devem manter um alto grau de higiene pessoal e usar uniformes ou roupas protetoras apropriadas, proteção para os cabelos e sapatos. Feridas e cortes devem ser cobertos com curativos a prova d'água, caso o funcionário possa continuar trabalhando, ou seja, desde que a lesão não apresente risco de contaminação do alimento manipulado. Os cabelos devem estar limpos, cortados e protegidos por uma touca ou rede de cabelo. Barba, bigode e costeletas também devem ser protegidos mas, de preferência, devem ser evitados por manipuladores de alimentos.

Está definido no Codex Alimentarius que:

"Caso haja necessidade de uso de luvas, elas devem ser sempre mantidas limpas e em perfeitas condições sanitárias. O fato de usar luvas não significa a desobrigação de lavar bem as mãos. As luvas devem ser feitas de materiais apropriados para o contato com alimentos, e se por algum motivo furarem ou rasgarem ocorrerá muito mais contaminação por causa do suor das mãos".

\subsection{Higiene dos Equipamentos e Utensílios}

Buscando minimizar o problema das toxinfecções alimentares, legislações, equipamentos e estudos buscam eliminar os possíveis focos de proliferação dos microorganismos prejudiciais à saúde.

Neste aspecto nota-se que em muitos casos valoriza-se os processos de segurança alimentar que envolvem o alimento e sua manipulação, relegando-se a um segundo plano o final da linha, ou seja, os processos de higienização dos utensílios que serão utilizados pelos usuários dos diversos pontos de alimentação.

Os cuidados com os equipamentos poderão evitar desde o aparecimento de corpos estranhos nos alimentos (resíduos de fuligem, gordura, restos de operações anteriores e partes de produtos abrasivos), resíduos de produtos e a ocorrência de contaminações químicas (produtos de 
limpeza e sanificação), físicas (esponjas, buchas, etc) e biológicas (bactérias, fungos, vírus, etc).

Como regra geral os equipamentos e utensílios devem encontrar-se em condições adequadas de conservação, funcionamento e limpeza, além de contar com um programa constante de manutenção preventiva.

Uma vez terminados os trabalhos de limpeza e desinfecção, os utensílios de higiene, com as vassouras, panos, baldes, etc., devem ser limpos, desinfetados e guardados bem secos, para evitar que esses implementos sejam causadores de contaminações cruzadas muito perigosas.

Os equipamentos portáteis com superfícies em contato com alimentos e utensílios, já limpos e higienizados, devem ser armazenados em local apropriado, de modo a proteger estas superfícies contra a contaminação.

Ainda não existe o material ideal para evitar a multiplicação microbiana. Em qualquer superfície em que haja resíduos orgânicos, umidade e temperatura adequada, pode ocorrer a multiplicação de microorganismos patogênicos. Alguns materiais deveriam ser evitados, tais como madeira, esmalte e outros produtos que soltem pedaços ou resíduos dom o uso.

\subsection{Higiene ambiental para eventos}

Ao destinar-se um espaço para realização de eventos, a preocupação com as instalações de cozinha e áreas de manipulação de alimentos é fundamental, já que muitos eventos estão configurados com prestação de serviço de alimentos. Torna-se evidente portanto a importância dessa preocupação, já que o sucesso do evento passa a depender também das condições de segurança alimentar oferecidas aos participantes.

Na produção de refeições, a área física da unidades de alimentação se constitui num ponto importante no processo de contaminação dos alimentos. A preocupação com esse ambiente deve se iniciar com um projeto que torne um ambiente saudável, previna as toxinfecções alimentares e englobe as instalações, áreas de trabalho, fluxo operacional e equipamentos. Falhas nesta fase de projeto, podem acarretar inclusive, dificuldades operacionais de limpeza e desinfecção das áreas. 
O não cumprimento destas ações, aliado a o fato de que muitos eventos acontecem em locais que não oferecem serviço de alimentação próprio, e é contratado um serviço terceirizado que não tem responsabilidade sob o espaço que ele tem para operar, os processos de controle são negligenciados e o serviço acontece em condições inadequadas. Como a maioria dos microorganismos se desenvolve sob condições favoráveis, a falta de compromisso com a desinfecção das instalações, áreas e equipamentos, fará com que a possibilidade de contaminação seja alta, o que compromete consideravelmente todo o evento.

Em pesquisa realizada em cozinhas dos estabelecimentos hoteleiros com variação de três a cinco estrelas dos setores norte e sul de Brasília, quase todos com espaço destinado a eventos, os resultados indicam que as unidades visitadas não cumprem as Boas Práticas de Fabricação, requisito legal para a fabricação de alimentos.

Não existem pesquisas que avaliam o nível de adequação de outros espaços destinados para eventos, mas a prática mostra que nestes espaços a situação é ainda mais precária no que diz respeito às instalações, utensílios, manipuladores, fluxo de produção e controles de qualidade.

"A higiene ambiental e as condições do local da cozinha podem contribuir decisivamente para a manutenção da qualidade original dos alimentos, podendo também agir como fonte de contaminantes que atuam como coadjuvantes no processo de contaminação e deterioração dos alimentos, podendo também trazer prejuízos para a saúde dos funcionários que trabalham sob essas condições" (Trigo, 1999, p. 95).

Para evitar as conseqüências indesejáveis das condições ambientais inadequadas nas áreas que preparam e/ou manipulam alimentos, devem ser seguidos alguns padrões mínimos para funcionamento de locais onde são recebidos, armazenados, preparados, servidos, transportados ou expostos para consumo.

\subsubsection{Pisos}

Devem ser revestidos de material liso, resistente, impermeável, que proporcione facilidade para higienização, além de estar em bom estado de 
conservação. Devem ser mantidos sempre secos nos períodos em que houver exposição de alimentos.

Deve haver sempre uma pessoa destinada especificamente para a higienização do ambiente e que preferencialmente não seja um manipulador de alimentos. Caso não haja um colaborador apenas para a limpeza, deve haver uma rotatividade das pessoas para a realização da higienização de forma a evitar que este colaborador venha a manipular alimentos. Em último caso se a pessoa responsável pela higienização do ambiente manipular alimentos, deve-se ter uma atenção especial para a higiene pessoal no que tange ao controle de contaminação de uniforme e processo correto de lavagem das mãos.

A limpeza do ambiente deve ser realizada da seguinte forma: primeiramente retirar do piso todo o resíduo que tenha caído durante a operação, com o uso de vassoura ou rodo e pá para recolher. Esses resíduos deverão ser despejados em vasilhames para lixo localizados em pontos estratégicos na cozinha. A seguir deverão ser providenciados três baldes de 20 litros com as seguintes soluções: $1^{\circ}$ balde - água e sabão (diluir o produto de acordo com especificação do fabricante). $2^{\circ}$ balde - somente água. $3^{\circ}$ balde - água e sanificante. Para cada balde deverá haver um pano de limpeza e a higienização do local deve seguir esta seqüência acima especificada, ou seja, eliminação dos resíduos, remoção da gordura com uso de produtos químicos, remoção do sabão ou detergente e sanificação.

\subsubsection{Paredes e azulejos}

De acordo com o código sanitário, as cozinhas deverão ter revestimento de material cerâmico vidrado até a altura mínima de dois metros e daí para cima pintada com cores claras de tinta lavável. Caso sejam utilizados azulejos estes deverão ser de cor clara, rejuntados com cimento branco sem falhas, rachaduras ou buracos que dificultam a limpeza e servem de abrigo para pragas.

O processo de limpeza deverá ser efetuado como o do piso. 


\subsubsection{Teto}

Devem ter acabamento liso, impermeável, cor clara e encontrar-se em bom estado de manutenção e limpeza, livre de rachaduras, descascamentos e bolores.

Também deve estar livre de vazamentos e goteiras, além de possuir proteção (telas metálicas milimétricas) para as aberturas existentes a fim de evitar o acesso de pragas e formação de ninhos.

\subsubsection{Portas e janelas}

As aberturas de acesso à área da cozinha deverão se protegidas por telas metálicas de malha fina. As portas deverão ser revestidas de material liso e lavável, é recomendada a aplicação de proteção metálica na parte inferior para evitar que roedores façam aberturas. As janelas também devem encontrar-se em bom estado de limpeza e conservação, serem preferencialmente feitas de alumínio ou de ferro. Poderão também auxiliar na ventilação e renovação de ar ambiente, sendo obrigatória a instalação de telas.

\subsection{Controle de tempo e temperatura dos alimentos}

\begin{tabular}{|c|c|c|c|}
\hline Alimento & $\begin{array}{c}\text { Temperatura } \\
\text { Mínima Interna }\end{array}$ & $\begin{array}{l}\text { Tempo Mínimo } \\
\text { de Duração }\end{array}$ & Observações \\
\hline Aves & $74^{\circ} \mathrm{C}$ & 15 segundos & \\
\hline $\begin{array}{l}\text { Recheio para aves, } \\
\text { empadas, carnes }\end{array}$ & $74^{\circ} \mathrm{C}$ & 15 segundos & \\
\hline $\begin{array}{l}\text { Carne de porco, } \\
\text { salsicha, bacon }\end{array}$ & $68^{\circ} \mathrm{C}$ & 15 segundos & \\
\hline Pescados & $63^{\circ} \mathrm{C}$ & 15 segundos & \\
\hline $\begin{array}{l}\text { Carne de vaca, } \\
\text { coelho, carneiro }\end{array}$ & $63^{\circ} \mathrm{C}$ & 15 segundos & $\begin{array}{l}\text { Se for possível } \\
\text { aumentar o tempo } \\
\text { ou a temperatura }\end{array}$ \\
\hline $\begin{array}{l}\text { Carne ou peixe } \\
\text { moidos }\end{array}$ & $68^{\circ} \mathrm{C}$ & 15 segundos & Aconselhável $74^{\circ} \mathrm{C}$ \\
\hline $\begin{array}{l}\text { Todos os alimentos } \\
\text { que não tenham } \\
\text { sido consumidos }\end{array}$ & $74^{\circ} \mathrm{C}$ & 15 segundos & $\begin{array}{l}\text { O tempo máximo } \\
\text { para alcançar a } \\
\text { Tmi é de } 2 \text { horas }\end{array}$ \\
\hline
\end{tabular}


imediatamente, que estiveram refrigerados, requentar a

Como regra geral os alimentos deverão ser cozidos até atingir uma temperatura interna de $80^{\circ} \mathrm{C}$ por um tempo de 10 minutos, independente da forma de preparação (assado, grelhado, frito, cozido, etc).

Em alguns pratos especiais poderá ser adotada a temperatura interna mínima de $68^{\circ} \mathrm{C}$ por 15 minutos, a fim de não alterar a apresentação e aparência do produto final acabado.

\subsubsection{Transporte de alimentos em eventos}

A não adequação do transporte às técnicas de prevenção, pode tornar o produto um veiculador de toxinfecção alimentar sem haver, necessariamente, falhas processuais anteriores.

Além do cuidado que o encarregado pelo transporte deve ter com o alimento, e com as condições em que este deve ser transportado, o tipo de veículo ou o recipiente exigido deve se adequar à natureza do alimento.

"Os veículos devem ser projetados e construídos de modo a não contaminarem os alimentos ou as embalagens; serem limpos e desinfetados quando necessário; permitirem a separação de diferentes alimentos ou destes e produtos não alimentícios durante o transporte; manter temperatura, umidade, pressão atmosférica e outras condições necessárias para proteger o alimento contra crescimento microbiano prejudicial ou indesejável e deterioração, tornando o produto impróprio ao consumo; e permitirem a verificação de temperatura, umidade ou outros fatores" (OPAS/OMS, 2001, p.91).

"Os ingredientes refrigerados devem ser transportados a $4^{\circ} \mathrm{C}\left(39,2^{\circ} \mathrm{F}\right)$ ou menos, e devem ser monitorados durante o transporte. Os ingredientes congelados devem ser mantidos a $-18^{\circ} \mathrm{C}\left(-0,4^{\circ} \mathrm{F}\right)$, tolerando-se até $-12^{\circ} \mathrm{C}$ $\left(10,4^{\circ} \mathrm{F}\right)$ para a recepção. Os alimentos devem ser transportados em condições que evitem contaminação microbiológica, física e química" (OPAS/OMS, 2001, p.92). 


\subsubsection{Armazenamento de alimentos em eventos}

De acordo com Silva Jr. (1995:85), alguns procedimentos devem ser seguidos para garantir a inocuidade dos alimentos durante seu armazenamento:

- A disposição dos produtos deve obedecer a data de fabricação, sendo que os produtos de fabricação mais antiga são posicionados a serem consumidos em primeiro lugar (PEPS - Primeiro que entra é o primeiro que sai). Pode-se também utilizar o conceito PVPS - primeiro que vence é o primeiro que sai;

- Deve-se manter a organização dos alimentos de acordo com o tipo de produto, tanto no estoque seco quanto nos equipamentos sob ar frio;

- As embalagens devem estar limpas;

- Tudo deve estar adequadamente identificado e protegido

- Os alimentos não devem ficar armazenados junto a produtos de limpeza, químicos ou de higiene.

- Produtos descartáveis também devem ser mantidos separados dos citados anteriormente;

- Não devem existir caixas de madeira em nenhuma área de armazenamento de alimentos;

- Devem ser evitadas caixas de papelão no estoque ou em áreas de armazenamento sob ar frio, a menos que seja um local exclusivo para esse fim;

- Alimentos ou recipientes com alimentos não devem estar em contato com o piso e sim apoiados sobre estrados ou prateleiras das estantes. Respeitar o espaçamento mínimo necessário que garanta a circulação de ar ambiente ou frio;

- O empilhamento no estoque deve ser alinhado e em altura que não prejudique as características do produto. As pilhas nos estrados, devem estar afastadas $10 \mathrm{~cm}$ da parede e a amarração em forma de cruz para favorecer a ventilação e evitar acidentes;

- Os alimentos apoiados nas prateleiras das estantes devem estar afastados da parede de preferência $35 \mathrm{~cm}$, sendo o mínimo aceitável 10 $\mathrm{cm}$, dependendo do tamanho da área de estoque;

- Qualquer alimento que necessite ser transferido da embalagem original deve ser acondicionado de forma que se mantenha protegido. 
Determinados alimentos, depois de abertos, também necessitam de transferência das embalagens originais (ex: latarias abertas). Nestes casos acondicionar em descartáveis, ou contentores de polietileno, ou outro recipiente adequado, higienizado. Na impossibilidade de manter o rótulo original do produto, as informações devem ser transcritas em etiqueta apropriada;

- Proteger os alimentos com saco plástico apropriado (nunca saco de lixo) ou papel impermeável. Essas embalagens não devem ser reaproveitadas;

- Quando houver necessidade de armazenar diferentes gêneros alimentícios em um mesmo equipamento refrigerador, respeitar; alimentos prontos para consumo dispostos nas prateleiras superiores, os semiprontos e/ou pré-preparados nas prateleiras do meio e o restante, como por exemplo, produtos cárneos crus, nas prateleiras inferiores, separados entre si e dos demais produtos;

- Poderá ser armazenado no mesmo equipamento para congelamento tipos diferentes de alimentos, desde que devidamente embalados e separados.

Os produtos podem ser conservados através de vários procedimentos, tanto físicos como químicos. Os mais utilizados são, a refrigeração e o congelamento. Neste caso é preciso agrupar os diferentes tipos de alimentos nas temperaturas que Ihes forma convenientes, ou seja:

- 7 a $10^{\circ} \mathrm{C}$ - Frutas;

- $\quad 4$ a $7^{\circ} \mathrm{C}$ - Vegetais, ovos, alimentos preparados;

- $\quad 3,5$ a $4,5^{\circ} \mathrm{C}$ - Leite e derivados;

- 1 a $4^{\circ} \mathrm{C}$ - Carne fresca;

- $\quad 0$ a $3^{\circ} \mathrm{C}$ - Aves, peixes e crustáceos;

- $-25 \mathrm{a}-18^{\circ} \mathrm{C}-$ Produtos congelados.

Os produtos conservados nas temperaturas adequadas não podem, nem por isso, ali permanecer por prazos indefinidos. Deve-se respeitar os seus prazos de validade. Neste sentido é necessário conhecer quais são esses prazos e, em vista disso, efetuar o rodízio necessário. 


\subsubsection{Distribuição de alimentos em eventos}

Na distribuição os alimentos deverão permanecer no máximo entre 30 a 40 minutos. Deverá ser calculada a quantidade por cuba, de forma que essa quantidade seja consumida dentro desse tempo recomendado, de acordo com o número de comensais e do tempo de duração do evento.

Como descrito acima, o balcão térmico deverá funcionar entre $85^{\circ} \mathrm{C} \mathrm{e}$ $90^{\circ} \mathrm{C}$, para garantir a temperatura interna mínima de $60^{\circ} \mathrm{C}$.

Os alimentos servidos frios deverão ser mantidos a $10^{\circ} \mathrm{C}$ por 30 minutos.

\section{As Boas Práticas de Fabricação como ferramenta para monitorar a qualidade dos alimentos}

As Boas Práticas de Fabricação são procedimentos que visam atingir um padrão de qualidade dos produtos e serviços na área de alimentos e bebidas, incluindo os materiais e utensílios em contato com os alimentos.

Estes procedimentos tratam dos cuidados no projeto da área física, instalações, no uso de equipamentos bem como mudanças nos métodos de produção e no comportamento das pessoas envolvidas nessa produção. Implica também em aperfeiçoamento no sistema de gestão, pois sugere a implementação de rotinas de inspeção e registros de controle documentados.

\section{O Sistema APPCC}

Em tempos de economia globalizada e mercados altamente competitivos são claras as necessidades de se elevar a qualidade das empresas prestadoras de serviço mediante o aperfeiçoamento de processos produtivos, redução dos custos de produção e melhoria da qualidade dos produtos.

No caso das empresas de alimentos inclui-se, ainda, garantir a segurança dos seus clientes através da inocuidade dos produtos. 
O sistema de Análises de Perigos e Pontos Críticos de Controle (APPCC), resulta-se da presença da Comissão do Codex Alimentarius no acordo com a Rodada do Uruguai e tornou-se desde então referência para as exigências internacionais de inocuidade alimentar.

O objetivo do sistema APPCC - Análise de Perigos e Pontos Críticos de Controle, é identificar os perigos relacionados à manipulação dos alimentos para o consumidor que podem ocorrer em um processo produtivo, estabelecendo controles para garantir um produto livre de contaminação.

O Sistema APPCC é preventivo, garantindo produtos isentos de contaminações que coloquem em risco a saúde dos consumidores. Por sua eficácia comprovada, o APPCC é recomendado por organismos internacionais como a OMC (Organização Mundial do Comércio), FAO (Organização das Nações Unidas para a Alimentação e Agricultura), OMS (Organização Mundial da Saúde), sendo exigido também pela Comunidade Comum Européia, pelos Estados Unidos, MERCOSUL e freqüentemente solicitado pelos que possuem sistemas de gestão e garantia da qualidade.

A adoção do Sistema APPCC tem como vantagens:

- Oferecer um alto nível de segurança dos alimentos;

- Contribuir para a redução de custos, não só por evitar análises do tipo "aceita/rejeita", mas também por reduzir a destruição ou reprocessamento de produtos, o que corresponde a um aumento de produtividade com qualidade e segurança;

- Contribuir para a redução das contagens microbianas e para o aumento do tempo de exposição dos produtos;

- Propiciar a manutenção dos clientes (cada vez mais exigentes por qualidade) e ajudar na conquista de novos clientes;

"O APPCC baseia-se em um sistema de engenharia conhecido como "Análise de Falhas, Modos e Efeitos",em que se observa, em cada etapa do processo, os erros que podem ocorrer, suas causas prováveis e seus efeitos, para então estabelecer o mecanismo de controle" OPAS/OMS (2001:113).

Este sistema é uma ferramenta de gerenciamento que oferece um programa efetivo de controle de perigos. É racional, pois baseia-se em dados registrados referentes a causas de enfermidades transmitidas por alimentos. 
É também lógico e abrangente, já que considera os ingredientes, o processo e o uso subsequente do produto.

Este sistema é contínuo, detectando-se os problemas antes que ocorram, ou no momento que surgem, e aplicando-se imediatamente as ações corretivas. É sistemático, por ser um plano completo, que cobre todas as operações, os processos e as medidas de controle, diminuindo o risco de contaminação do alimento.

A implantação do sistema APPCC reduz a necessidade de inspeção e teste do produto final, aumenta a confiança do consumidor e resulta num produto comercialmente mais viável. Facilita o cumprimento de exigências legais, e permite o uso mais eficiente de recursos, acarretando redução nos custos da indústria de alimentos e uma resposta mais imediata para as questões de segurança alimentar.

\section{Considerações Finais}

Ainda mais importante que atender bem um cliente antes e durante seu evento, é fazer com que ele confie na empresa e na equipe que contratou.

Quando um cliente promove um evento com serviços de alimentos e bebidas, seja ele de qual tipo for, há sempre uma grande expectativa, seja por um significado profissional ou sentimental, quando ele procura uma empresa prestadora de serviços de $A \& B$ e eventos, ele quer oferecer para seus convidados algo que fique positivamente registrado em suas memórias.

É muito especial cuidar dessas impressões. E a melhor ferramenta para superar as expectativas e encantar esses clientes, é sem dúvida o profissionalismo que só pode ser conquistado através da educação.

O segmento de eventos profissionais é recente, fato que eleva ainda mais a necessidade de aperfeiçoamento das pessoas envolvidas nesta atividade. Muito se fala em atendimento, e ele é realmente fundamental, mas em tempos de preocupação com a saúde e cuidados com o que se come fora de casa, a segurança alimentar passa a ser fator decisivo na hora de escolher um produto ou um serviço. 
Coordenar um evento exige muito mais que preparar um local para receber convidados. É fundamental fazer com que esses convidados percebam todos os aspectos tangíveis e intangíveis com cercam o evento, dentre eles os aspectos relacionados à segurança alimentar.

Trabalhando com eventos, pude perceber que muitos profissionais que atuam na área desconhecem estes preceitos e acabam colocando em risco todo seu trabalho. Desejo que esta monografia possa contribuir para o aperfeiçoamento de outros profissionais da hospitalidade assim como ele contribuiu para a melhoria do meu trabalho.

\section{Referências Bibliográficas}

TRIGO, V.C. Manual Prático de Higiene e Sanidade nas Unidades de Alimentação e Nutrição. $2^{\circ}$ ed. Sao Paulo: Livraria Varela, 1999.

OMT, (Tradução: Cláudia Bruno Galvãn). Manual de Qualidade, Higiene e Inocuidade dos Alimentos no Setor de Turismo. $1^{\circ}$ ed. São Paulo: Roca, 2003.

CASTELLI, G. Administração Hoteleira. $8^{\circ}$ ed. Caxias do Sul: EDUCS, 2001.

SILVA Jr, E. A. da. Manual de Controle Higiênico-sanitário em Alimentos. $1^{\circ}$ ed. São Paulo: Livraria Varela, 1999.

DAVIES, C. A. Alimentos e Bebidas. $2^{\circ}$ ed. Caxias do Sul: EDUCS, 2001.

Revista Higiene Alimentar - Vol.15 n 82

SAUDE, ORGANIZAÇÃO PAN AMERICANA DA. HACCP: Instrumento para Inocuidade de Alimentos. $1^{\circ}$ ed. Buenos Aires: OPAS/INPPAZ, 2001.

TRIGO, V.C. Manual Prático de higiene de sanidade das unidades de alimentação e nutrição. $1^{\circ}$ ed. São Paulo: Livraria Varela, 1999.

BRASIL. Decreto-Lei $n^{\circ}$ 986, de 21 de outubro de 1969. Institui Normas Básicas sobre Alimentos.

BRASIL. Ministério da Saúde. Secretaria de Vigilância Sanitária. Portaria $\mathrm{n}^{\circ}$ 326, de 30 de julho de 1997. Regulamento Técnico sobre as Condições Higiênico Sanitárias 
10. ANEXOS 


\begin{abstract}
ANEXO I
REGULAMENTO TÉCNICO DE PROCEDIMENTOS OPERACIONAIS PADRONIZADOS APLICADOS AOS ESTABELECIMENTOS PRODUTORES/INDUSTRIALIZADORES DE ALIMENTOS
\end{abstract}

\title{
1. ALCANCE
}

\subsection{Objetivo}

Estabelecer Procedimentos Operacionais Padronizados que contribuam para a garantia das condições higiênico-sanitárias necessárias ao processamento/industrialização de alimentos, complementando as Boas Práticas de Fabricação.

1.2. Âmbito de Aplicação

Aplica-se aos estabelecimentos processadores/industrializadores nos quais sejam realizadas algumas das seguintes atividades: produção/industrialização, fracionamento, armazenamento e transporte de alimentos industrializados.

\section{DEFINIÇÕES}

Para efeito deste Regulamento, considera-se:

2.1. Procedimento Operacional Padronizado - POP: procedimento escrito de forma objetiva que estabelece instruções seqüenciais para a realização de operações rotineiras e específicas na produção, armazenamento e transporte de alimentos. Este Procedimento pode apresentar outras nomenclaturas desde que obedeça ao conteúdo estabelecido nesta Resolução.

2.2. Limpeza: operação de remoção de terra, resíduos de alimentos, sujidades e ou outras substâncias indesejáveis.

2.3. Desinfecção: operação de redução, por método físico e ou agente químico, do número de microrganismos a um nível que não comprometa a segurança do alimento. 2.4. Higienização: operação que se divide em duas etapas, limpeza e desinfecção. 2.5. Anti-sepsia: operação destinada à redução de microrganismos presentes na pele, por meio de agente químico, após lavagem, enxágüe e secagem das mãos.

2.6. Controle Integrado de Pragas: sistema que incorpora ações preventivas e corretivas destinadas a impedir a atração, o abrigo, o acesso e ou proliferação de vetores e pragas urbanas que comprometam a segurança do alimento.

2.7. Programa de recolhimento de alimentos: procedimentos que permitem efetivo recolhimento e apropriado destino final de lote de alimentos exposto à comercialização com suspeita ou constatação de causar dano à saúde.

2.8. Resíduos: materiais a serem descartados, oriundos da área de produção e das demais áreas do estabelecimento.

2.9. Manual de Boas Práticas de Fabricação: documento que descreve as operações realizadas pelo estabelecimento, incluindo, no mínimo, os requisitos sanitários dos edifícios, a manutenção e higienização das instalações, dos equipamentos e dos utensílios, o controle da água de abastecimento, o controle integrado de vetores e pragas urbanas, controle da higiene e saúde dos manipuladores e o controle e garantia de qualidade do produto final.

\section{REQUISITOS PARA ELABORAÇÃO DOS PROCEDIMENTOS OPERACIONAIS PADRONIZADOS}




\subsection{Requisitos Gerais}

3.1.1. Os estabelecimentos produtores/industrializadores de alimentos devem desenvolver, implementar e manter para cada item relacionado abaixo, Procedimentos Operacionais Padronizados - POPs.

a) Higienização das instalações, equipamentos, móveis e utensílios.

b) Controle da potabilidade da água.

c) Higiene e saúde dos manipuladores.

d) Manejo dos resíduos.

e) Manutenção preventiva e calibração de equipamentos.

f) Controle integrado de vetores e pragas urbanas.

g) Seleção das matérias-primas, ingredientes e embalagens.

h) Programa de recolhimento de alimentos.

3.1.2. Os POPs devem ser aprovados, datados e assinados pelo responsável técnico, responsável pela operação, responsável legal e ou proprietário do estabelecimento, firmando o compromisso de implementação, monitoramento, avaliação, registro e manutenção dos mesmos.

3.1.3. A freqüência das operações e nome, cargo e ou função dos responsáveis por sua execução devem estar especificados em cada POP.

3.1.4. Os funcionários devem estar devidamente capacitados para execução dos POPs. 3.1.5. Quando aplicável, os POPs devem relacionar os materiais necessários para a realização das operações assim como os Equipamentos de Proteção Individual.

3.1.6. Os POPs devem estar acessíveis aos responsáveis pela execução das operações e às autoridades sanitárias.

3.1.7. Os POPs podem ser apresentados como anexo do Manual de Boas Práticas de Fabricação do estabelecimento.

3.2. Requisitos específicos

3.2.1. Os POPs referentes às operações de higienização de instalações, equipamentos, móveis e utensílios devem conter informações sobre: natureza da superfície a ser higienizada, método de higienização, princípio ativo selecionado e sua concentração, tempo de contato dos agentes químicos e ou físicos utilizados na operação de higienização, temperatura e outras informações que se fizerem necessárias. Quando aplicável o desmonte dos equipamentos, os POPs devem contemplar esta operação. 3.2.2. Os Procedimentos Operacionais Padronizados devem abordar as operações relativas ao controle da potabilidade da água, incluindo as etapas em que a mesma é crítica para o processo produtivo, especificando os locais de coleta das amostras, a freqüência de sua execução, as determinações analíticas, a metodologia aplicada e os responsáveis. Quando a higienização do reservatório for realizada pelo próprio estabelecimento, os procedimentos devem contemplar os tópicos especificados no item 3.2.1. Nos casos em que as determinações analíticas e ou a higienização do reservatório forem realizadas por empresas terceirizadas, o estabelecimento deve apresentar, para o primeiro caso, o laudo de análise e, para o segundo, o certificado de execução do serviço contendo todas as informações constantes no item 4.2.1.

3.2.3. As etapas, a freqüência e os princípios ativos usados para a lavagem e anti-sepsia das mãos dos manipuladores devem estar documentados em procedimentos operacionais, assim como as medidas adotadas nos casos em que os manipuladores apresentem lesão nas mãos, sintomas de enfermidade ou suspeita de problema de saúde que possa comprometer a segurança do alimento. Deve-se especificar os exames aos quais os manipuladores de alimentos são submetidos, bem como a periodicidade de sua execução. O programa de capacitação dos manipuladores em higiene deve ser descrito, sendo determinada a carga horária, o conteúdo programático e a freqüência de sua 
realização, mantendo-se em arquivo os registros da participação nominal dos funcionários.

3.2.4. Os Procedimentos Operacionais Padronizados devem estabelecer a freqüência e o responsável pelo manejo dos resíduos. Da mesma forma, os procedimentos de higienização dos coletores de resíduos e da área de armazenamento devem ser discriminados atendendo, no mínimo, aos tópicos especificados no item 4.2.1.

3.2.5. Os estabelecimentos devem dispor dos Procedimentos Operacionais Padronizados que especifiquem a periodicidade e responsáveis pela manutenção dos equipamentos envolvidos no processo produtivo do alimento. Esses POPs devem também contemplar a operação de higienização adotada após a manutenção dos equipamentos. Devem ser apresentados os POPs relativos à calibração dos instrumentos e equipamentos de medição ou comprovante da execução do serviço quando a calibração for realizada por empresas terceirizadas.

3.2.6. Os POPs referentes ao controle integrado de vetores e pragas urbanas devem contemplar as medidas preventivas e corretivas destinadas a impedir a atração, o abrigo, o acesso e ou a proliferação de vetores e pragas urbanas. No caso da adoção de controle químico, o estabelecimento deve apresentar comprovante de execução de serviço fornecido pela empresa especializada contratada, contendo as informações estabelecidas em legislação sanitária específica.

3.2.7. O estabelecimento deve dispor de procedimentos operacionais especificando os critérios utilizados para a seleção e recebimento da matéria-prima, embalagens e ingredientes, e, quando aplicável, o tempo de quarentena necessário. Esses procedimentos devem prever o destino dado às matérias-primas, embalagens e ingredientes reprovados no controle efetuado.

3.2.8. O programa de recolhimento de produtos deve ser documentado na forma de procedimentos operacionais, estabelecendo-se as situações de adoção do programa, os procedimentos a serem seguidos para o rápido e efetivo recolhimento do produto, a forma de segregação dos produtos recolhidos e seu destino final, além dos responsáveis pela atividade.

\section{MONITORAMENTO, AVALIAÇÃO E REGISTRO DOS PROCEDIMENTOS OPERACIONAIS PADRONIZADOS}

4.1. A implementação dos POPs deve ser monitorada periodicamente de forma a garantir a finalidade pretendida, sendo adotadas medidas corretivas em casos de desvios destes procedimentos. As ações corretivas devem contemplar o destino do produto, a restauração das condições sanitárias e a reavaliação dos Procedimentos Operacionais Padronizados.

4.2. Deve-se prever registros periódicos suficientes para documentar a execução e o monitoramento dos Procedimentos Operacionais Padronizados, bem como a adoção de medidas corretivas. Esses registros consistem de anotação em planilhas e ou documentos e devem ser datados, assinados pelo responsável pela execução da operação e mantidos por um período superior ao tempo de vida de prateleira do produto. 4.3. Deve-se avaliar, regularmente, a efetividade dos POPs implementados pelo estabelecimento e, de acordo com os resultados, deve-se fazer os ajustes necessários. 4.4. Os Procedimentos Operacionais Padronizados devem ser revistos em caso de modificação que implique em alterações nas operações documentadas. 


\section{ANEXO II \\ LISTA DE VERIFICAÇÃO DAS BOAS PRÁTICAS DE FABRICAÇÃO EM ESTABELECIMENTOS PRODUTORES/INDUSTRIALIZADORES DE ALIMENTOS}

\begin{tabular}{|c|c|c|}
\hline \multicolumn{3}{|l|}{ NÚMERO: IANO } \\
\hline \multicolumn{3}{|l|}{ A - IDENTIFICAÇÃO DA EMPRESA } \\
\hline \multicolumn{3}{|l|}{ 1-RAZÃO SOCIAL: } \\
\hline \multicolumn{3}{|l|}{ 2-NOME DE FANTASIA: } \\
\hline 3-ALVARÁ/LICENÇA SANITÁRIA: & \multicolumn{2}{|c|}{ 4-INSCRIÇÃO ESTADUAL / MUNICIPAL: } \\
\hline 5-CNPJ / CPF: & 6-FONE: & 7-FAX: \\
\hline \multicolumn{3}{|l|}{ 8-E - mail: } \\
\hline 9-ENDEREÇO (Rua/Av.): & 10-No: & 11-Compl.: \\
\hline 12-BAIRRO: & 13-MUNICÍPIO: & 14-UF: $15-C E P:$ \\
\hline 16-RAMO DE ATIVIDADE: & \multicolumn{2}{|c|}{ 17-PRODUÇÃO MENSAL: } \\
\hline 18-NÚMERO DE FUNCIONÁRIOS: & \multicolumn{2}{|c|}{ 19-NÚMERO DE TURNOS: } \\
\hline \multicolumn{3}{|l|}{ 20-CATEGORIA DE PRODUTOS: } \\
\hline \multicolumn{3}{|l|}{ Descrição da Categoria: } \\
\hline \multicolumn{3}{|l|}{ Descrição da Categoria: } \\
\hline \multicolumn{3}{|l|}{ Descrição da Categoria: } \\
\hline \multicolumn{3}{|l|}{ Descrição da Categoria: } \\
\hline \multicolumn{3}{|l|}{ Descrição da Categoria: } \\
\hline 21-RESPONSÁVEL TÉCNICO: & \multicolumn{2}{|c|}{ 22-FORMAÇÃO ACADÊMICA: } \\
\hline \multicolumn{3}{|c|}{ 23-RESPONSÁVEL LEGAL/PROPRIETÁRIO DO ESTABELECIMENTO: } \\
\hline \multicolumn{3}{|c|}{$\begin{array}{l}\text { 24-MOTIVO DA INSPEÇÃO: ( ) SOLICITAÇÃO DE LICENÇA SANITÁRIA ( ) COMUNICAÇÃO } \\
\text { DO INÍCIO DE FABRICAÇÃO DE PRODUTO DISPENSADO DA OBRIGATORIEDADE DE } \\
\text { REGISTRO ( ) SOLICITAÇÃO DE REGISTRO }\end{array}$} \\
\hline \multicolumn{3}{|c|}{$\begin{array}{l}\text { () PROGRAMAS ESPECÍFICOS DE VIGILÂNCIA SANITÁRIA ( ) VERIFICAÇÃO OU } \\
\text { APURAÇÃO DE DENUUNCIA ( ) INSPEÇÂO PROGRAMADA ( ) REINSPEÇÂO }\end{array}$} \\
\hline \multicolumn{3}{|c|}{ () RENOVAÇÃO DE LICENÇA SANITÁRIA ( ) RENOVAÇÃO DE REGISTRO ( ) OUTROS } \\
\hline
\end{tabular}

\begin{tabular}{|c|c|c|c|}
\hline \multirow{2}{*}{$\begin{array}{l}\text { B - AVALIAÇÃO } \\
\text { 1. EDIFICAÇÃO E INSTALAÇÕES }\end{array}$} & SIM & NÃO & $N A\left(^{*}\right)$ \\
\hline & & & \\
\hline 1.1 ÁREA EXTERNA: & & & \\
\hline $\begin{array}{l}\text { 1.1.1 Área externa livre de focos de insalubridade, de objetos em desuso } \\
\text { ou estranhos ao ambiente, de vetores e outros animais no pátio e } \\
\text { vizinhança; de focos de poeira; de acúmulo de lixo nas imediações, de } \\
\text { água estagnada, dentre outros. }\end{array}$ & & & \\
\hline $\begin{array}{l}\text { 1.1.2 Vias de acesso interno com superfície dura ou pavimentada, } \\
\text { adequada ao trânsito sobre rodas, escoamento adequado e limpas }\end{array}$ & & & \\
\hline
\end{tabular}




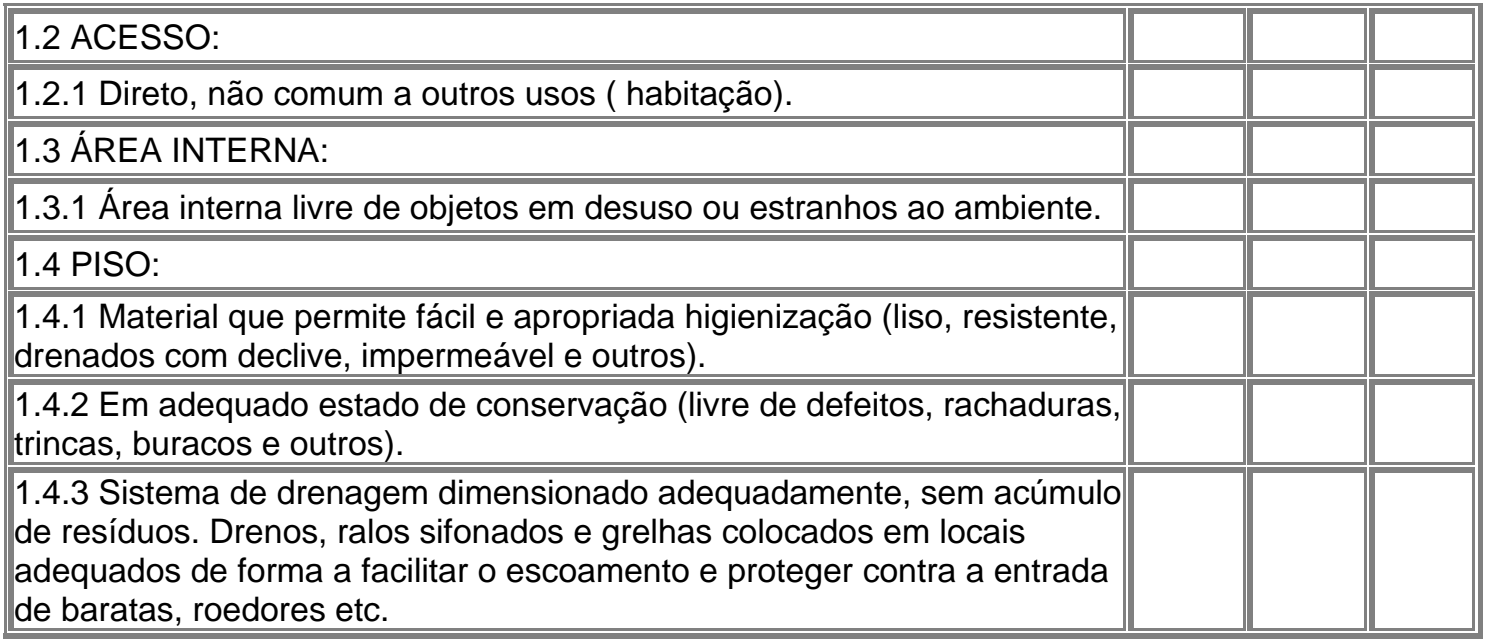

\begin{tabular}{|c|c|c|c|}
\hline B - AVALIAÇÃO & SIM & NÃO & $N A(*)$ \\
\hline \multicolumn{4}{|l|}{ 1.5 TETOS: } \\
\hline \multicolumn{4}{|l|}{$\begin{array}{l}\text { 1.5.1 Acabamento liso, em cor clara, impermeável, de fácil limpeza e, } \\
\text { quando for o caso, desinfecção. }\end{array}$} \\
\hline \multicolumn{4}{|l|}{$\begin{array}{l}\text { 1.5.2 Em adequado estado de conservação (livre de trincas, rachaduras, } \\
\text { umidade, bolor, descascamentos e outros). }\end{array}$} \\
\hline \multicolumn{4}{|l|}{ 1.6 PAREDES E DIVISÓRIAS: } \\
\hline \multicolumn{4}{|l|}{$\begin{array}{l}\text { 1.6.1 Acabamento liso, impermeável e de fácil higienização até uma altura } \\
\text { adequada para todas as operações. De cor clara. }\end{array}$} \\
\hline \multicolumn{4}{|l|}{$\begin{array}{l}\text { 1.6.2 Em adequado estado de conservação (livres de falhas, rachaduras, } \\
\text { umidade, descascamento e outros). }\end{array}$} \\
\hline \multicolumn{4}{|l|}{$\begin{array}{l}\text { 1.6.3 Existência de ângulos abaulados entre as paredes e o piso e entre } \\
\text { as paredes e o teto. }\end{array}$} \\
\hline \multicolumn{4}{|l|}{ 1.7 PORTAS: } \\
\hline \multicolumn{4}{|l|}{$\begin{array}{l}\text { 1.7.1 Com superfície lisa, de fácil higienização, ajustadas aos batentes, } \\
\text { sem falhas de revestimento. }\end{array}$} \\
\hline \multicolumn{4}{|l|}{$\begin{array}{l}\text { 1.7.2 Portas externas com fechamento automático (mola, sistema } \\
\text { eletrônico ou outro) e com barreiras adequadas para impedir entrada de } \\
\text { vetores e outros animais (telas milimétricas ou outro sistema). }\end{array}$} \\
\hline \multicolumn{4}{|l|}{$\begin{array}{l}\text { 1.7.3 Em adequado estado de conservação (livres de falhas, rachaduras, } \\
\text { umidade, descascamento e outros). }\end{array}$} \\
\hline \multicolumn{4}{|l|}{ 1.8 JANELAS E OUTRAS ABERTURAS: } \\
\hline \multicolumn{4}{|l|}{$\begin{array}{l}\text { 1.8.1 Com superfície lisa, de fácil higienização, ajustadas aos batentes, } \\
\text { sem falhas de revestimento. }\end{array}$} \\
\hline \multicolumn{4}{|l|}{$\begin{array}{l}\text { 1.8.2 Existência de proteção contra insetos e roedores (telas milimétricas } \\
\text { ou outro sistema). }\end{array}$} \\
\hline \multicolumn{4}{|l|}{$\begin{array}{l}\text { 1.8.3 Em adequado estado de conservação (livres de falhas, rachaduras, } \\
\text { umidade, descascamento e outros). }\end{array}$} \\
\hline \multicolumn{4}{|l|}{$\begin{array}{l}\text { 1.9 ESCADAS, ELEVADORES DE SERVIÇO, MONTACARGAS E } \\
\text { ESTRUTURAS AUXILIARES }\end{array}$} \\
\hline 1.9.1 Construídos, localizados e utilizados de forma a não serem fontes de & & & \\
\hline
\end{tabular}




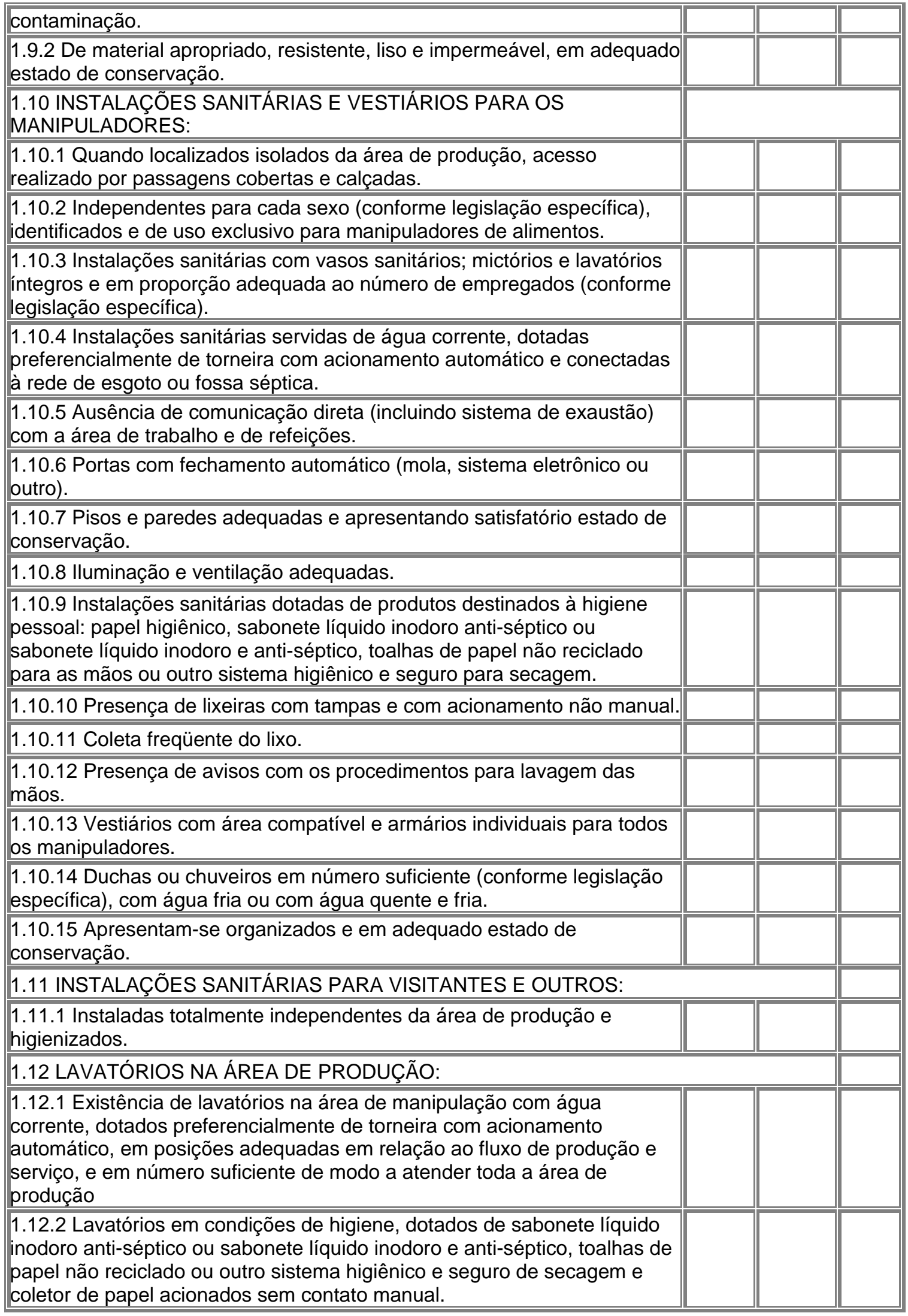




\begin{tabular}{|c|c|c|c|}
\hline B - AVALIAÇÃO & SIM & NÃO & $\mathrm{NA}\left({ }^{*}\right)$ \\
\hline \multicolumn{4}{|l|}{ 1.13 ILUMINAÇÃO E INSTALAÇÃO ELÉTRICA: } \\
\hline \multicolumn{4}{|l|}{$\begin{array}{l}\text { 1.13.1 Natural ou artificial adequada à atividade desenvolvida, sem } \\
\text { ofuscamento, reflexos fortes, sombras e contrastes excessivos. }\end{array}$} \\
\hline \multicolumn{4}{|l|}{$\begin{array}{l}\text { 1.13.2 Luminárias com proteção adequada contra quebras e em } \\
\text { adequado estado de conservação. }\end{array}$} \\
\hline \multicolumn{4}{|l|}{$\begin{array}{l}\text { 1.13.3 Instalações elétricas embutidas ou quando exteriores revestidas } \\
\text { por tubulações isolantes e presas a paredes e tetos. }\end{array}$} \\
\hline \multicolumn{4}{|l|}{ 1.14 VENTILAÇÃO E CLIMATIZAÇÃO: } \\
\hline \multicolumn{4}{|l|}{$\begin{array}{l}\text { 1.14.1 Ventilação e circulação de ar capazes de garantir o conforto } \\
\text { térmico e o ambiente livre de fungos, gases, fumaça, pós, partículas em } \\
\text { suspensão e condensação de vapores sem causar danos à produção. }\end{array}$} \\
\hline \multicolumn{4}{|l|}{$\begin{array}{l}\text { 1.14.2 Ventilação artificial por meio de equipamento(s) higienizado(s) e } \\
\text { com manutenção adequada ao tipo de equipamento. }\end{array}$} \\
\hline \multicolumn{4}{|l|}{ 1.14.3 Ambientes climatizados artificialmente com filtros adequados. } \\
\hline \multicolumn{4}{|l|}{$\begin{array}{l}\text { 1.14.4 Existência de registro periódico dos procedimentos de limpeza e } \\
\text { manutenção dos componentes do sistema de climatização (conforme } \\
\text { legislação específica) afixado em local visível. }\end{array}$} \\
\hline \multicolumn{4}{|l|}{$\begin{array}{l}\text { 1.14.5 Sistema de exaustão e ou insuflamento com troca de ar capaz de } \\
\text { prevenir contaminações. }\end{array}$} \\
\hline \multicolumn{4}{|l|}{$\begin{array}{l}\text { 1.14.6 Sistema de exaustão e ou insuflamento dotados de filtros } \\
\text { adequados. }\end{array}$} \\
\hline \multicolumn{4}{|l|}{$\begin{array}{l}\text { 1.14.7 Captação e direção da corrente de ar não seguem a direção da } \\
\text { área contaminada para área limpa. }\end{array}$} \\
\hline \multicolumn{4}{|l|}{ 1.15 HIGIENIZAÇÃO DAS INSTALAÇÕES: } \\
\hline \multicolumn{4}{|l|}{$\begin{array}{l}\text { 1.15.1 Existência de um responsável pela operação de higienização } \\
\text { comprovadamente capacitado. }\end{array}$} \\
\hline \multicolumn{4}{|l|}{ 1.15.2 Freqüência de higienização das instalações adequada. } \\
\hline \multicolumn{4}{|l|}{ 1.15.3 Existência de registro da higienização. } \\
\hline \multicolumn{4}{|l|}{ 1.15.4 Produtos de higienização regularizados pelo Ministério da Saúde. } \\
\hline \multicolumn{4}{|l|}{$\begin{array}{l}\text { 1.15.5 Disponibilidade dos produtos de higienização necessários à } \\
\text { realização da operação. }\end{array}$} \\
\hline \multicolumn{4}{|l|}{$\begin{array}{l}\text { 1.15.6 A diluição dos produtos de higienização, tempo de contato e modo } \\
\text { de uso/aplicação obedecem às instruções recomendadas pelo fabricante. }\end{array}$} \\
\hline \multicolumn{4}{|l|}{$\begin{array}{l}\text { 1.15.7 Produtos de higienização identificados e guardados em local } \\
\text { adequado. }\end{array}$} \\
\hline \multicolumn{4}{|l|}{$\begin{array}{l}\text { 1.15.8 Disponibilidade e adequação dos utensílios (escovas, esponjas } \\
\text { etc.) necessários à realização da operação. Em bom estado de } \\
\text { conservação. }\end{array}$} \\
\hline \multicolumn{4}{|l|}{ 1.15.9 Higienização adequada. } \\
\hline \multicolumn{4}{|l|}{ 1.16 CONTROLE INTEGRADO DE VETORES E PRAGAS URBANAS: } \\
\hline \multicolumn{4}{|l|}{$\begin{array}{l}\text { 1.16.1 Ausência de vetores e pragas urbanas ou qualquer evidência de } \\
\text { sua presença como fezes, ninhos e outros. }\end{array}$} \\
\hline 1.16.2 Adoção de medidas preventivas e corretivas com o objetivo de & & & \\
\hline
\end{tabular}




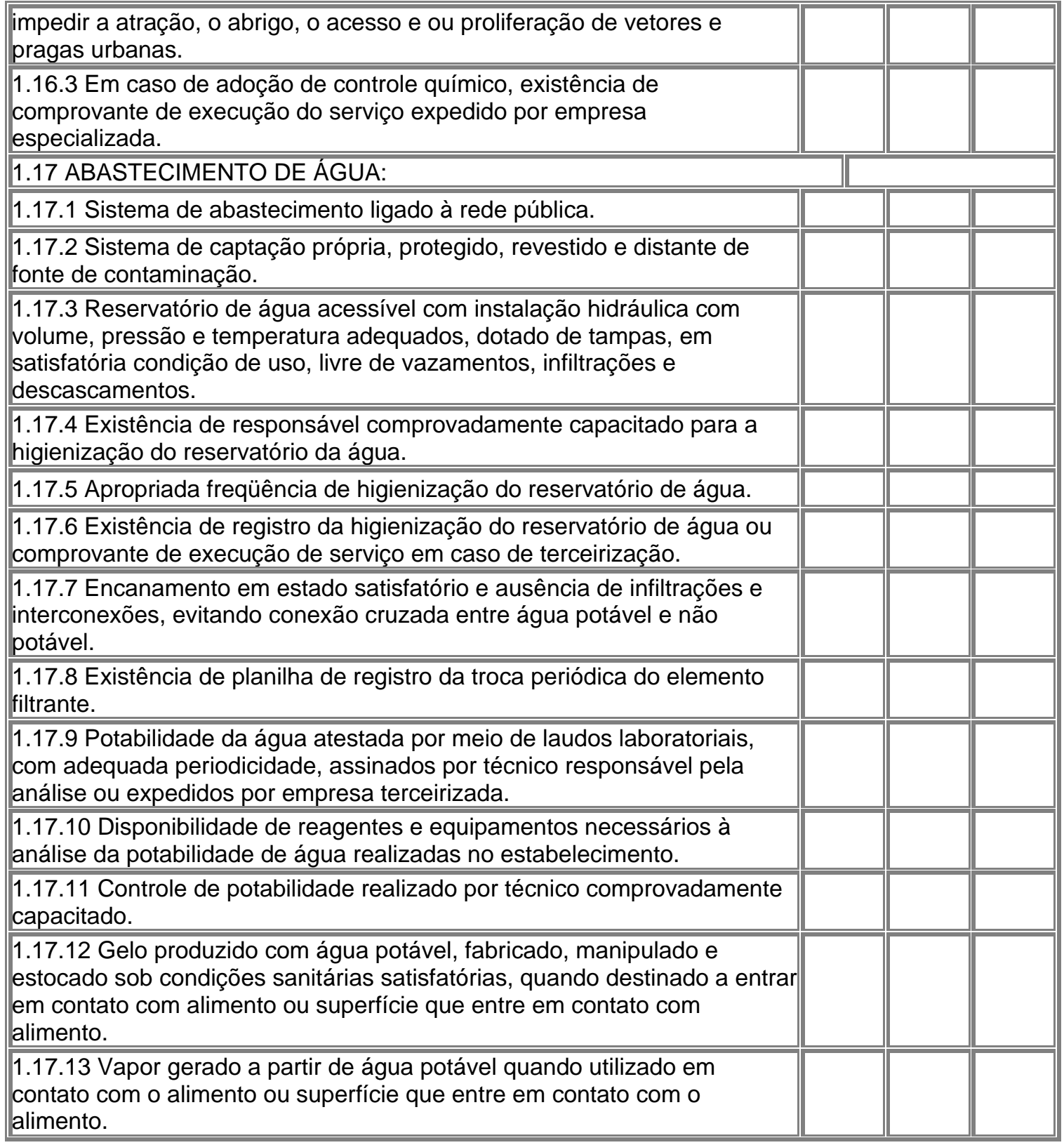

\begin{tabular}{|c|c|c|c|}
\hline B - AVALIAÇÃO & SIM & NÃO & $\mathrm{NA}\left({ }^{*}\right)$ \\
\hline \multicolumn{4}{|l|}{ 1.18 MANEJO DOS RESÍDUOS: } \\
\hline \multicolumn{4}{|l|}{$\begin{array}{l}\text { 1.18.1 Recipientes para coleta de resíduos no interior do estabelecimento } \\
\text { de fácil higienização e transporte, devidamente identificados e } \\
\text { higienizados constantemente; uso de sacos de lixo apropriados. Quando } \\
\text { necessário, recipientes tampados com acionamento não manual. }\end{array}$} \\
\hline \multicolumn{4}{|l|}{$\begin{array}{l}\text { 1.18.2 Retirada freqüente dos resíduos da área de processamento, } \\
\text { evitando focos de contaminação. }\end{array}$} \\
\hline \multicolumn{4}{|l|}{ 1.18.3 Existência de área adequada para estocagem dos resíduos. } \\
\hline 1.19 ESGOTAMENTO SANITÁRIO: & & & \\
\hline
\end{tabular}




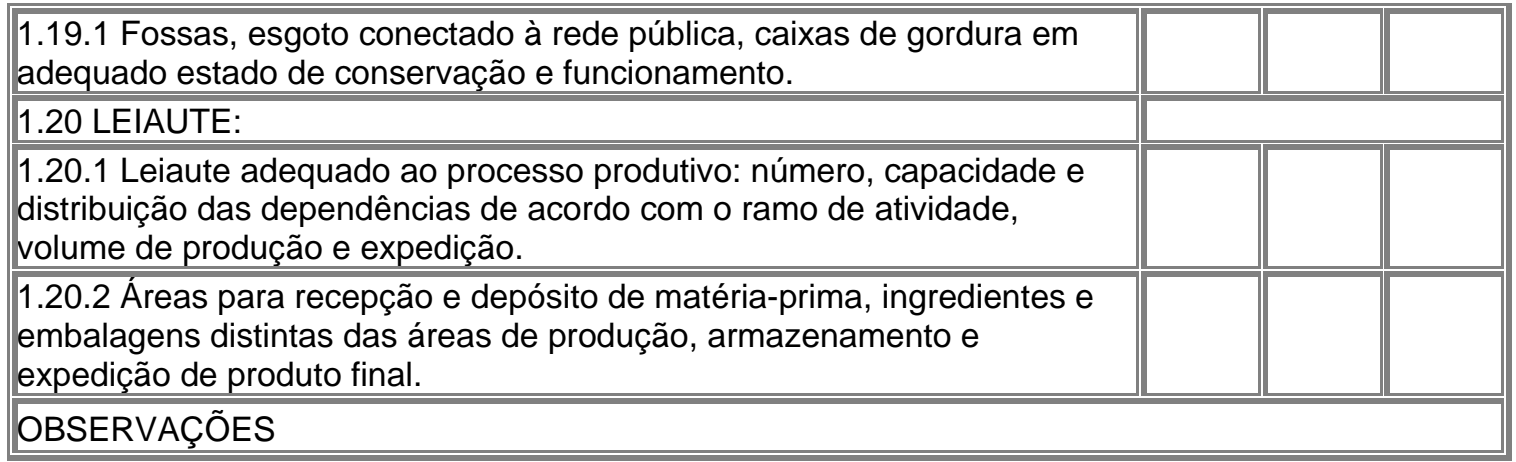

\begin{tabular}{|c|c|c|}
\hline B - AVALIAÇÃO & NÃO & $\mathrm{NA}\left({ }^{*}\right)$ \\
\hline \multicolumn{3}{|l|}{ 2. EQUIPAMENTOS, MÓVEIS E UTENSÍLIOS } \\
\hline \multicolumn{3}{|l|}{2.1 EQUIPAMENTOS: } \\
\hline \multicolumn{3}{|l|}{$\begin{array}{l}\text { 2.1.1 Equipamentos da linha de produção com desenho e número } \\
\text { adequado ao ramo. }\end{array}$} \\
\hline \multicolumn{3}{|l|}{ 2.1.2 Dispostos de forma a permitir fácil acesso e higienização adequada. } \\
\hline \multicolumn{3}{|l|}{$\begin{array}{l}\text { 2.1.3 Superfícies em contato com alimentos lisas, íntegras, impermeáveis, } \\
\text { resistentes à corrosão, de fácil higienização e de material não } \\
\text { contaminante. }\end{array}$} \\
\hline \multicolumn{3}{|l|}{ 2.1.4 Em adequado estado de conservação e funcionamento. } \\
\hline \multicolumn{3}{|l|}{$\begin{array}{l}\text { 2.1.5 Equipamentos de conservação dos alimentos (refrigeradores, } \\
\text { congeladores, câmaras frigoríficas e outros), bem como os destinados ao } \\
\text { processamento térmico, com medidor de temperatura localizado em local } \\
\text { apropriado e em adequado funcionamento. }\end{array}$} \\
\hline \multicolumn{3}{|l|}{$\begin{array}{l}\text { 2.1.6 Existência de planilhas de registro da temperatura, conservadas } \\
\text { durante período adequado. }\end{array}$} \\
\hline \multicolumn{3}{|l|}{$\begin{array}{l}\text { 2.1.7 Existência de registros que comprovem que os equipamentos e } \\
\text { maquinários passam por manutenção preventiva. }\end{array}$} \\
\hline \multicolumn{3}{|l|}{$\begin{array}{l}\text { 2.1.8 Existência de registros que comprovem a calibração dos } \\
\text { instrumentos e equipamentos de medição ou comprovante da execução } \\
\text { do serviço quando a calibração for realizada por empresas terceirizadas. }\end{array}$} \\
\hline \multicolumn{3}{|l|}{ 2.2 MÓVEIS: (mesas, bancadas, vitrines, estantes) } \\
\hline \multicolumn{3}{|l|}{$\begin{array}{l}2.2 .1 \text { Em número suficiente, de material apropriado, resistentes, } \\
\text { impermeáveis; em adequado estado de conservação, com superfícies } \\
\text { íntegras. }\end{array}$} \\
\hline \multicolumn{3}{|l|}{$\begin{array}{l}\text { 2.2.2 Com desenho que permita uma fácil higienização (lisos, sem } \\
\text { rugosidades e frestas). }\end{array}$} \\
\hline \multicolumn{3}{|l|}{2.3 UTENSÍLIOS: } \\
\hline \multicolumn{3}{|l|}{$\begin{array}{l}\text { 2.3.1 Material não contaminante, resistentes à corrosão, de tamanho e } \\
\text { forma que permitam fácil higienização: em adequado estado de } \\
\text { conservação e em número suficiente e apropriado ao tipo de operação } \\
\text { utilizada. }\end{array}$} \\
\hline \multicolumn{3}{|l|}{$\begin{array}{l}\text { 2.3.2 Armazenados em local apropriado, de forma organizada e } \\
\text { protegidos contra a contaminação. }\end{array}$} \\
\hline $\begin{array}{l}\text { 2.4 HIGIENIZAÇÃO DOS EQUIPAMENTOS E MAQUINÁRIOS, E DOS } \\
\text { MÓVEIS E UTENSÍLIOS: }\end{array}$ & & \\
\hline
\end{tabular}




\begin{tabular}{|c|c|c|c|}
\hline $\begin{array}{l}\text { 2.4.1 Existência de um responsável pela operação de higienização } \\
\text { comprovadamente capacitado. }\end{array}$ & & & \\
\hline 2.4.2 Freqüência de higienização adequada. & & & \\
\hline 2.4.3 Existência de registro da higienização. & & & \\
\hline 2.4.4 Produtos de higienização regularizados pelo Ministério da Saúde. & & & \\
\hline $\begin{array}{l}\text { 2.4.5 Disponibilidade dos produtos de higienização necessários à } \\
\text { realização da operação. }\end{array}$ & & & \\
\hline $\begin{array}{l}\text { 2.4.6 Diluição dos produtos de higienização, tempo de contato e modo de } \\
\text { uso/aplicação obedecem às instruções recomendadas pelo fabricante. }\end{array}$ & & & \\
\hline $\begin{array}{l}\text { 2.4.7 Produtos de higienização identificados e guardados em local } \\
\text { adequado. }\end{array}$ & & & \\
\hline $\begin{array}{l}\text { 2.4.8 Disponibilidade e adequação dos utensílios necessários à realização } \\
\text { da operação. Em bom estado de conservação. }\end{array}$ & & & \\
\hline 2.4.9 Adequada higienização. & & & \\
\hline OBSERVAÇÕES & & & \\
\hline B - AVALIAÇÃO & SIM & NÃO & $\mathrm{NA}(*)$ \\
\hline 3. MANIPULADORES & & & \\
\hline 3.1 VESTUÁRIO: & & & \\
\hline $\begin{array}{l}\text { 3.1.1 Utilização de uniforme de trabalho de cor clara, adequado à } \\
\text { atividade e exclusivo para área de produção. }\end{array}$ & & & \\
\hline 3.1.2 Limpos e em adequado estado de conservação. & & & \\
\hline $\begin{array}{l}\text { 3.1.3 Asseio pessoal: boa apresentação, asseio corporal, mãos limpas, } \\
\text { unhas curtas, sem esmalte, sem adornos (anéis, pulseiras, brincos, etc.); } \\
\text { manipuladores barbeados, com os cabelos protegidos. }\end{array}$ & & & \\
\hline 3.2 HÁBITOS HIGIÊNICOS: & & & \\
\hline $\begin{array}{l}\text { 3.2.1 Lavagem cuidadosa das mãos antes da manipulação de alimentos, } \\
\text { principalmente após qualquer interrupção e depois do uso de sanitários. }\end{array}$ & & & \\
\hline $\begin{array}{l}\text { 3.2.2 Manipuladores não espirram sobre os alimentos, não cospem, não } \\
\text { tossem, não fumam, não manipulam dinheiro ou não praticam outros atos } \\
\text { que possam contaminar o alimento. }\end{array}$ & & & \\
\hline $\begin{array}{l}\text { 3.2.3 Cartazes de orientação aos manipuladores sobre a correta lavagem } \\
\text { das mãos e demais hábitos de higiene, afixados em locais apropriados. }\end{array}$ & & & \\
\hline 3.3 ESTADO DE SAÚDE: & & & \\
\hline $\begin{array}{l}\text { 3.3.1 Ausência de afecções cutâneas, feridas e supurações; ausência de } \\
\text { sintomas e infecções respiratórias, gastrointestinais e oculares. }\end{array}$ & & & \\
\hline 3.4 PROGRAMA DE CONTROLE DE SAÚDE: & & & \\
\hline $\begin{array}{l}\text { 3.4.1 Existência de supervisão periódica do estado de saúde dos } \\
\text { manipuladores. }\end{array}$ & & & \\
\hline 3.4.2 Existência de registro dos exames realizados. & & & \\
\hline 3.5 EQUIPAMENTO DE PROTEÇÃO INDIVIDUAL: & & & \\
\hline 3.5.1 Utilização de Equipamento de Proteção Individual. & & & \\
\hline $\begin{array}{l}\text { 3.6 PROGRAMA DE CAPACITAÇÃO DOS MANIPULADORES E } \\
\text { SUPERVISÃO: }\end{array}$ & & & \\
\hline $\begin{array}{l}\text { 3.6.1 Existência de programa de capacitação adequado e contínuo } \\
\text { relacionado à higiene pessoal e à manipulação dos alimentos. }\end{array}$ & & & \\
\hline
\end{tabular}




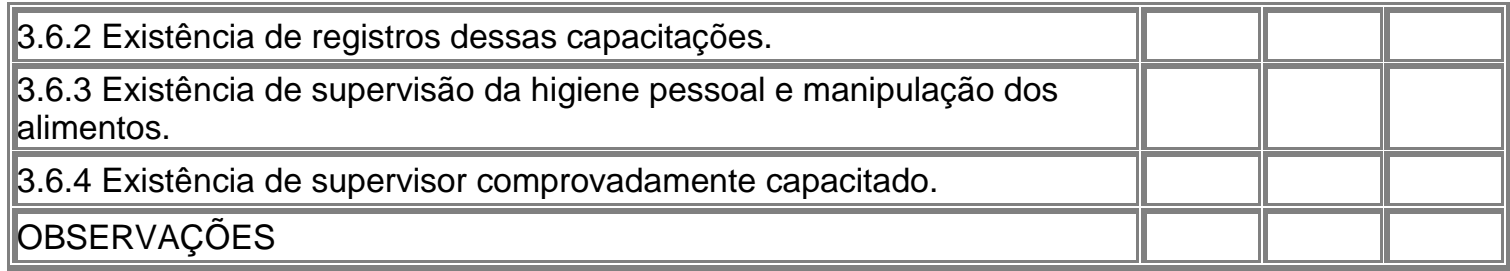

\begin{tabular}{|c|c|c|c|}
\hline \multirow{2}{*}{\multicolumn{4}{|c|}{$\begin{array}{l}\text { B - AVALIAÇÃO } \\
\text { 4. PRODUÇÃO E TRANSPORTE DO ALIMENTO }\end{array}$}} \\
\hline & & & \\
\hline \multicolumn{4}{|l|}{ 4.1 MATÉRIA-PRIMA, INGREDIENTES E EMBALAGENS: } \\
\hline \multicolumn{4}{|l|}{$\begin{array}{l}\text { 4.1.1 Operações de recepção da matéria-prima, ingredientes e } \\
\text { embalagens são realizadas em local protegido e isolado da área de } \\
\text { processamento. }\end{array}$} \\
\hline \multicolumn{4}{|l|}{$\begin{array}{l}\text { 4.1.2 Matérias - primas, ingredientes e embalagens inspecionados na } \\
\text { recepção. }\end{array}$} \\
\hline \multicolumn{4}{|l|}{$\begin{array}{l}\text { 4.1.3 Existência de planilhas de controle na recepção (temperatura e } \\
\text { características sensoriais, condições de transporte e outros). }\end{array}$} \\
\hline \multicolumn{4}{|l|}{$\begin{array}{l}\text { 4.1.4 Matérias-primas e ingredientes aguardando liberação e aqueles } \\
\text { aprovados estão devidamente identificados. }\end{array}$} \\
\hline \multicolumn{4}{|l|}{$\begin{array}{l}\text { 4.1.5 Matérias-primas, ingredientes e embalagens reprovados no controle } \\
\text { efetuado na recepção são devolvidos imediatamente ou identificados e } \\
\text { armazenados em local separado. }\end{array}$} \\
\hline \multicolumn{4}{|l|}{ 4.1.6 Rótulos da matéria-prima e ingredientes atendem à legislação. } \\
\hline \multicolumn{4}{|l|}{$\begin{array}{l}\text { 4.1.7 Critérios estabelecidos para a seleção das matérias-primas são } \\
\text { baseados na segurança do alimento. }\end{array}$} \\
\hline \multicolumn{4}{|l|}{$\begin{array}{l}\text { 4.1.8 Armazenamento em local adequado e organizado; sobre estrados } \\
\text { distantes do piso, ou sobre paletes, bem conservados e limpos, ou sobre } \\
\text { outro sistema aprovado, afastados das paredes e distantes do teto de } \\
\text { forma que permita apropriada higienização, iluminação e circulação de ar. }\end{array}$} \\
\hline \multicolumn{4}{|l|}{$\begin{array}{l}\text { 4.1.9 Uso das matérias-primas, ingredientes e embalagens respeita a } \\
\text { ordem de entrada dos mesmos, sendo observado o prazo de validade. }\end{array}$} \\
\hline \multicolumn{4}{|l|}{ 4.1.10 Acondicionamento adequado das embalagens a serem utilizadas. } \\
\hline \multicolumn{4}{|l|}{$\begin{array}{l}\text { 4.1.11 Rede de frio adequada ao volume e aos diferentes tipos de } \\
\text { matérias-primas e ingredientes. }\end{array}$} \\
\hline \multicolumn{4}{|l|}{ 4.2 FLUXO DE PRODUÇÃO: } \\
\hline \multicolumn{4}{|l|}{$\begin{array}{l}\text { 4.2.1 Locais para pré - preparo ("área suja") isolados da área de preparo } \\
\text { por barreira física ou técnica. }\end{array}$} \\
\hline \multicolumn{4}{|l|}{ 4.2.2 Controle da circulação e acesso do pessoal. } \\
\hline \multicolumn{4}{|l|}{$\begin{array}{l}\text { 4.2.3 Conservação adequada de materiais destinados ao } \\
\text { reprocessamento. }\end{array}$} \\
\hline 4.2.4 Ordenado, linear e sem cruzamento. & & & \\
\hline
\end{tabular}

\begin{tabular}{|c|c|c|c|}
\hline B - AVALIAÇÃO & SIM & NÃO & NA(*) \\
\hline \multicolumn{4}{|l|}{ 4.3 ROTULAGEM E ARMAZENAMENTO DO PRODUTO-FINAL: } \\
\hline 4.3.1 Dizeres de rotulagem com identificação visível e de acordo com a & & & \\
\hline
\end{tabular}




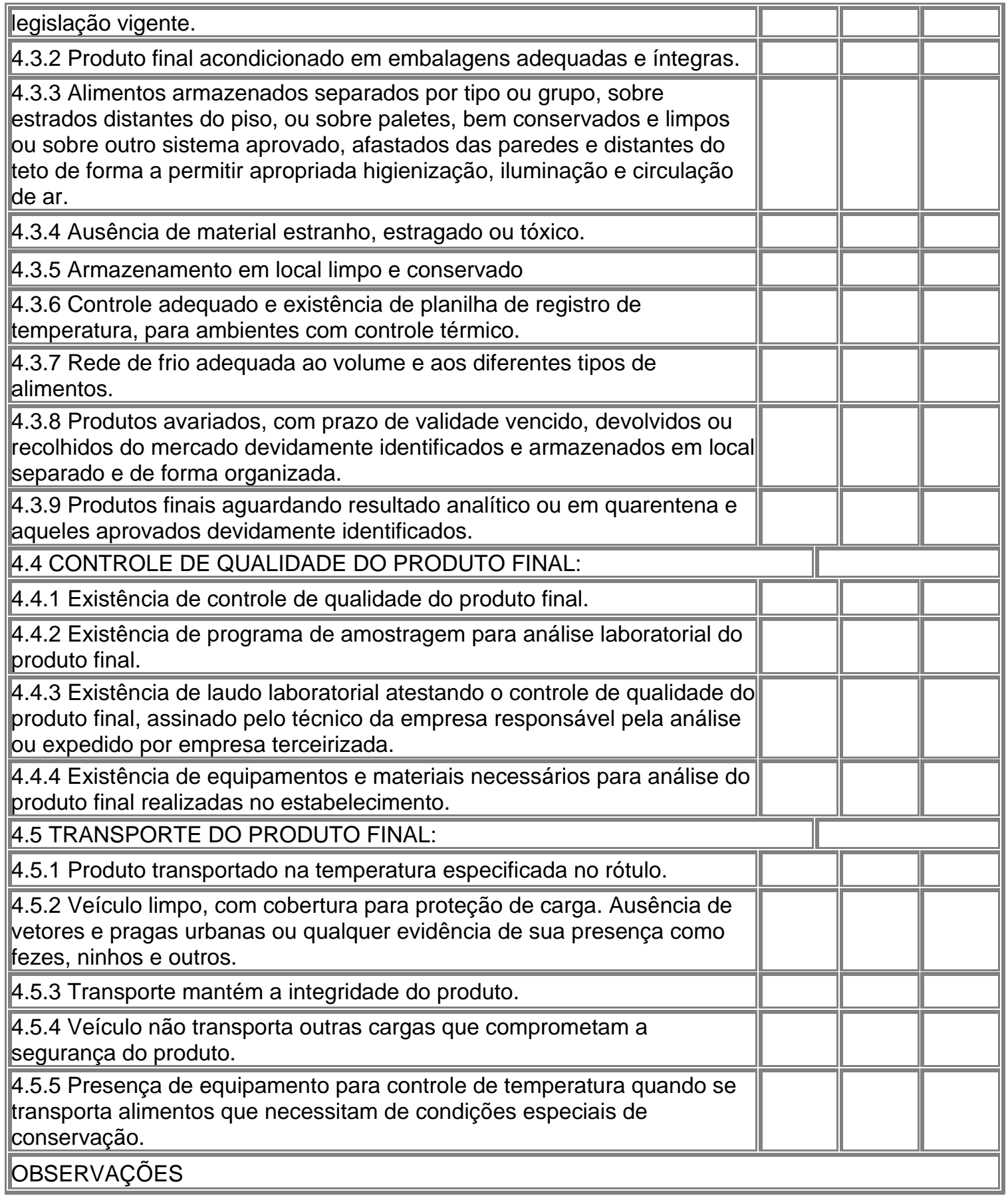

\begin{tabular}{|c|c|c|c|}
\hline \multirow{2}{*}{\multicolumn{4}{|c|}{$\begin{array}{l}\text { B - AVALIAÇÃO } \\
\text { 5. DOCUMENTAÇÃO }\end{array}$}} \\
\hline & & & \\
\hline \multicolumn{4}{|l|}{ 5.1 MANUAL DE BOAS PRÁTICAS DE FABRICAÇÃO: } \\
\hline $\begin{array}{l}\text { 5.1.1 Operações executadas no estabelecimento estão de acordo com o } \\
\text { Manual de Boas Práticas de Fabricação. }\end{array}$ & & & \\
\hline
\end{tabular}




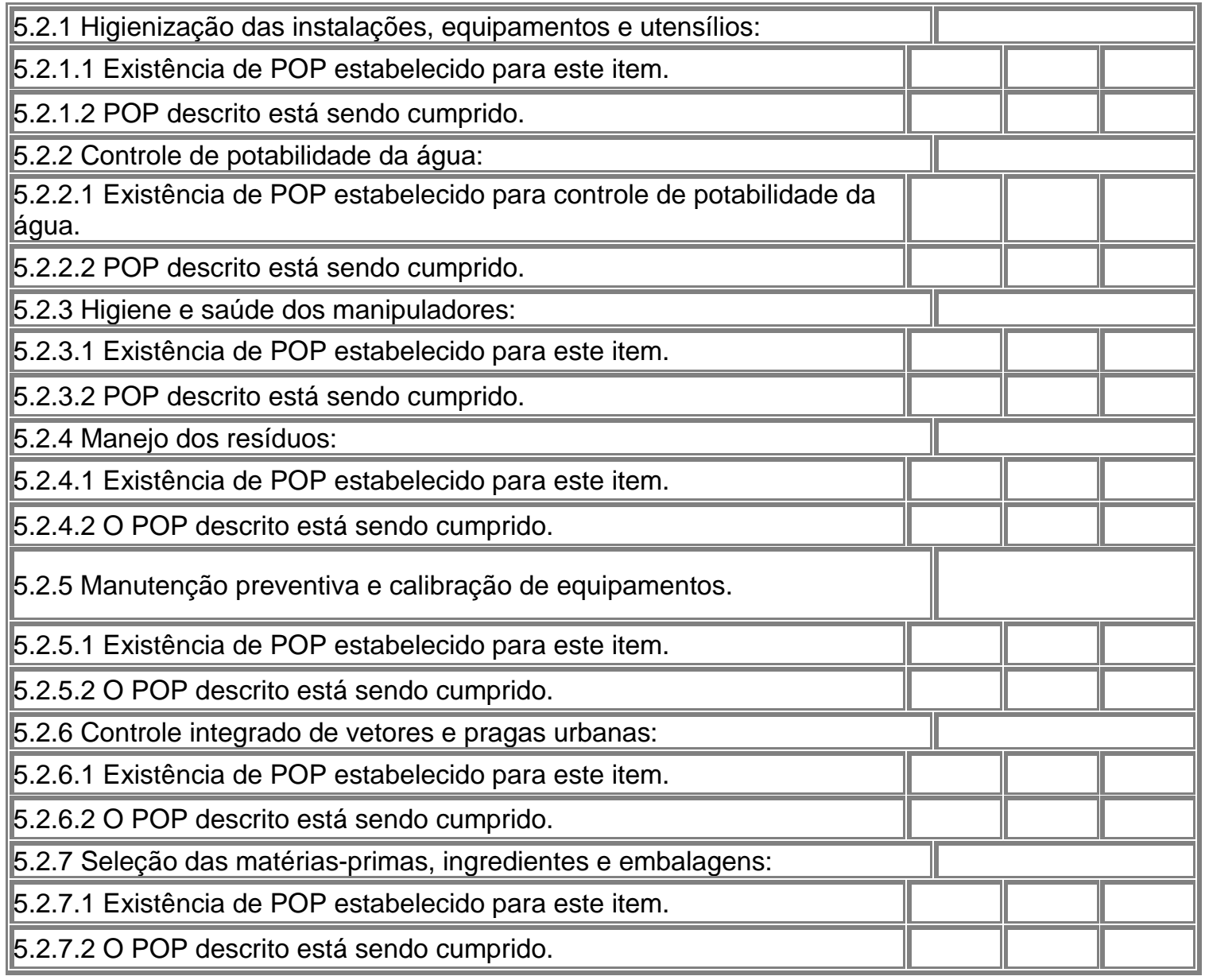

\begin{tabular}{|c|c|c|c|}
\hline B - AVALIAÇÃO & SIM & NÃO & $\mathrm{NA}\left({ }^{*}\right)$ \\
\hline 5.2.8 Programa de recolhimento de alimentos: & & & \\
\hline 5.2.8.1 Existência de POP estabelecido para este item. & & & \\
\hline 5.2.8.2 O POP descrito está sendo cumprido. & & & \\
\hline OBSERVAÇÕES & & & \\
\hline
\end{tabular}

\begin{tabular}{||l||}
\hline C - CONSIDERAÇÕES FINAIS \\
\hline
\end{tabular}

\section{D - CLASSIFICAÇÃO DO ESTABELECIMENTO}

Compete aos órgãos de vigilância sanitária estaduais e distrital, em articulação com o órgão competente no âmbito federal, a construção do panorama sanitário dos estabelecimentos produtores/industrializadores de alimentos, mediante sistematização dos dados obtidos nesse item. O panorama sanitário será utilizado como critério para definição e priorização das estratégias institucionais de intervenção. 
( ) GRUPO 1 - 76 A 100\% de atendimento dos itens ( ) GRUPO 2 - 51 A 75\% de atendimento dos itens () GRUPO 3 - 0 A 50\% de atendimento dos itens

\begin{tabular}{|c|c|}
\hline E - RESPONSÁVEIS PELA INSPEÇÃO & \\
\hline $\begin{array}{ll}\text { assinatura do responsável Matrícula: } & \text { Nome e }\end{array}$ & \begin{tabular}{|l|l} 
& Nome e \\
assinatura do responsável Matrícula:
\end{tabular} \\
\hline
\end{tabular}

\section{F - RESPONSÁVEL PELA EMPRESA}

Nome e assinatura do responsável pelo

estabelecimento

\begin{tabular}{|l||l|l|}
\hline LOCAL: & DATA: _ I \\
\hline \hline
\end{tabular}




\begin{abstract}
ANEXO III
Resolução - RDC n 275, de 21 de outubro de 2002(*)

Republicada no D.O.U de 06/11/2002

Dispõe sobre o Regulamento Técnico de Procedimentos Operacionais Padronizados aplicados aos Estabelecimentos Produtores/Industrializadores de Alimentos e a Lista de Verificação das Boas Práticas de Fabricação em Estabelecimentos Produtores/Industrializadores de Alimentos.

A Diretoria Colegiada da Agência Nacional de Vigilância Sanitária no uso da atribuição que lhe confere o art. 11, inciso IV, do Regulamento da ANVISA aprovado pelo Decreto $\mathrm{n}^{\circ}$ 3.029 , de 16 de abril de 1999 , c/c o $\S 1^{\circ}$ do art. 111 do Regimento Interno aprovado pela Portaria $n^{\circ} 593$, de 25 de agosto de 2000, republicada no DOU de 22 de dezembro de 2000 , em reunião realizada em 16 de outubro de 2002,

considerando a necessidade de constante aperfeiçoamento das ações de controle sanitário na área de alimentos visando a proteção à saúde da população;

considerando a necessidade de harmonização da ação de inspeção sanitária em estabelecimentos produtores/industrializadores de alimentos em todo o território nacional;

considerando a necessidade de complementar o Regulamento Técnico sobre as Condições Higiênico-Sanitárias e de Boas Práticas de Fabricação para Estabelecimentos Produtores/Industrializadores de Alimentos;

considerando a necessidade de desenvolvimento de um instrumento genérico de verificação das Boas Práticas de Fabricação aplicável aos estabelecimentos produtores/industrializadores de alimentos;

considerando que a Lista de Verificação restringe-se especificamente às Boas Práticas de Fabricação de Alimentos;

considerando que a atividade de inspeção sanitária deve ser complementada com a avaliação dos requisitos sanitários relativos ao processo de fabricação, bem como outros que se fizerem necessários;

considerando que os estabelecimentos podem utilizar nomenclaturas para os procedimentos operacionais padronizados diferentes da adotada no Anexo I desta Resolução, desde que obedeça ao conteúdo especificado nos mesmos,

adota a seguinte Resolução de Diretoria Colegiada e eu, Diretor-Presidente, determino a sua publicação:
\end{abstract}

Art. $1^{\circ}$ Aprovar o Regulamento Técnico de Procedimentos Operacionais Padronizados aplicados aos Estabelecimentos Produtores/Industrializadores de Alimentos e a Lista de Verificação das Boas Práticas de Fabricação em Estabelecimentos Produtores/Industrializadores de Alimentos. 
Art. $2^{\circ}$ As empresas têm o prazo de 180 (cento e oitenta) dias, a contar da data de publicação, para se adequarem ao Regulamento Técnico de Procedimentos Operacionais Padronizados aplicados a Estabelecimentos Produtores/Industrializadores de Alimentos, constante do Anexo I desta Resolução.

Art. $3^{\circ} \mathrm{A}$ avaliação do cumprimento do Regulamento Técnico constante do Anexo I e do Regulamento Técnico sobre as Condições Higiênico-Sanitárias e de Boas Práticas de Fabricação para Estabelecimentos Produtores/Industrializadores de Alimentos, aprovado pela Portaria SVS/MS n 326, de 30 de julho de 1997, dar-se-á por intermédio da Lista de Verificação das Boas Práticas de Fabricação em Estabelecimentos Produtores/Industrializadores de Alimentos constante do Anexo II.

$\S 1^{\circ}$ Os estabelecimentos devem atender de imediato a todos os itens discriminados na Lista de Verificação das Boas Práticas de Fabricação em Estabelecimentos Produtores/Industrializadores de Alimentos.

$\S 2{ }^{\circ}$ Excetuam-se do prazo estipulado no parágrafo anterior os itens relativos ao Regulamento Técnico de Procedimentos Operacionais Padronizados aplicados a Estabelecimentos Produtores/Industrializadores de Alimentos sendo considerado o prazo de adequação estipulado no art. $2^{\circ}$.

Art. $4^{\circ} \mathrm{A}$ Lista de Verificação das Boas Práticas de Fabricação em Estabelecimentos Produtores/Industrializadores de Alimentos, constante do Anexo II, não se aplica aos estabelecimentos que apresentem regulamento técnico específico.

Art. $5^{\circ} \mathrm{O}$ atendimento dos requisitos constantes da Lista de Verificação das Boas Práticas de Fabricação não exclui a obrigatoriedade das exigências relativas ao controle sanitário do processo produtivo.

Art. $6^{\circ} \mathrm{A}$ inobservância ou desobediência ao disposto na presente Resolução configura infração de natureza sanitária, na forma da Lei n 6437, de 20 de agosto de 1977, sujeitando o infrator às penalidades previstas nesse diploma legal.

Art. $7^{\circ}$ Esta Resolução de Diretoria Colegiada entrará em vigor na data de sua publicação. 
Portaria SVSIMS n 326, de 30 de julho de 1997

D.O. de 01/08/97

\section{REGULAMENTO TÉCNICO SOBRE AS CONDIÇÕES HIGIÊNICO-SANITÁRIAS E DE BOAS PRÁTICAS DE FABRICAÇÃO PARA ESTABELECIMENTOS PRODUTORE/INDUSTRIALIZADORES DE ALIMENTOS}

\section{OBJETIVO}

O presente Regulamento estabelece os requisitos gerais (essenciais) de higiene e de boas práticas de fabricação para alimentos produzidos /fabricados para o consumo humano.

\section{2. ÂMBITO DE APLICAÇÃO}

O presente Regulamento se aplica, quando for o caso, a toda pessoa física ou jurídica que possua pelo menos um estabelecimento no qual sejam realizadas algumas das atividades seguintes; produção/industrialização, fracionamento, armazenamento e transportes de alimentos industrializados.

O cumprimento dos requisitos gerais deste Regulamento não excetua o cumprimento de outros Regulamentos específicos que devem ser publicados.

\section{DEFINIÇÕES}

Para efeitos deste Regulamento são definidos:

3.1 - Adequado: se entende como suficiente para alcançar a finalidade proposta;

3.2 - Alimento apto para o consumo humano: aqui considerado como alimento que atende ao padrão de identidade e qualidade pré-estabelecido, nos aspectos higiênico-sanitários e nutricionais.

3.3 - Armazenamento: é o conjunto de atividades e requisitos para se obter uma correta conservação de matéria-prima, insumos e produtos acabados.

3.4 - Boas práticas: são os procedimentos necessários para garantir a qualidade dos alimentos.

3.5 - Contaminação: presença de substâncias ou agentes estranhos, de origem biológica, química ou física que sejam considerados nocivos ou não para saúde humana.

3.6 - Desinfecção: é a redução, através de agentes químicos ou métodos físicos adequados, do número de microorganismos no prédio, instalações, maquinários e utensílios, a um nível que não origine contaminação do alimento que será elaborado .

3.7 - Estabelecimento de alimentos produzidos/industrializados: é a região que compreende o local e sua circunvizinhança, no qual se efetua um conjunto de operações e processos, com a finalidade de obter um alimento elaborado, assim como o armazenamento ou o transporte de alimentos e/ou suas matérias primas. 
3.8 - Fracionamento de alimentos: são as operações através das quais se divide um alimento, sem modificar sua composição original.

3.9 - Limpeza: é a eliminação de terra, restos de alimentos, pó e outras matérias indesejáveis.

3.10 - Manipulação de alimentos: são as operações que são efetuadas sobre a matéria-prima até a obtenção de um alimento acabado, em qualquer etapa de seu processamento, armazenamento e transporte.

3.11 - Material de Embalagem: todos os recipientes como latas, garrafas, caixas de papelão, outras caixas, sacos ou materiais para envolver ou cobrir, tais como papel laminado, películas, plástico, papel encerado e tela.

3.12 - Órgão competente: é o órgão oficial ou oficialmente reconhecido ao qual o País Ihe autorga mecanismos legais para exercer suas funções.

3.13 - Pessoal Tecnicamente Competente/Responsabilidade Técnica: é o profissional habilitado a exercer atividade na área de produção de alimentos e respectivos controles de contaminantes que possa intervir com vistas à proteção da saúde.

3.14 - Pragas: os animais capazes de contaminar direta ou indiretamente os alimentos.

3.15 - Produção de Alimentos: é o conjunto de todas as operações e processos efetuados para obtenção de um alimento acabado.

\section{4 - PRINCÍPIOS GERAIS HIGIÊNICO-SANITÁRIOS DAS MATÉRIAS PARA ALIMENTOS PRODUZIDOS IINDUSTRIALIZADOS}

4.1- Áreas inadequadas de produção, criação, extração, cultivo ou colheita:

Não devem ser produzidos, cultivados, nem coletados ou extraídos alimentos ou criação de animais destinados à alimentação humana, em áreas onde a presença de substâncias potencialmente nocivas possam provocar a contaminação destes alimentos ou seus derivados, em níveis que possam constituir um risco para saúde.

\section{2 - Controle de prevenção da contaminação por lixo/sujidades:}

As matérias-primas alimentícias devem ter controle de prevenção da contaminação por lixos ou sujidades de origem animal, doméstico, industrial e agrícola, cuja presença possa atingir níveis passíveis de constituir um risco para saúde.

\section{3 - Controle de água:}

Não devem ser cultivados, produzidos nem extraídos alimentos ou criações de animais destinados à alimentação humana, em áreas onde a água utilizada nos diversos processos produtivos possa constituir, através de alimentos, um risco a saúde do consumidor.

\section{4 - Controle de pragas ou doenças:}

As medidas de controle que compreende o tratamento com agentes químicos, biológicos ou físicos devem ser aplicadas somente sob a supervisão direta do pessoal tecnicamente competente que saiba identificar, avaliar e intervir nos perigos potenciais que estas substâncias representam para a saúde. 
Tais medidas somente devem ser aplicadas em conformidade com as recomendações do órgão oficial competente.

4.5 - Colheita, produção, extração e abate:

4.5.1- Os métodos e procedimentos para colheita, produção, extração e abate devem ser higiênicos, sem constituir um perigo potencial para a saúde e nem provocar a contaminação dos produtos.

4.5.2- Equipamentos e recipientes que são utilizados nos diversos processos produtivos não devem constituir um risco à saúde.

Os recipientes que são reutilizáveis devem ser fabricados de material que permita a limpeza e desinfecção completa. Uma vez usados com matérias tóxicas não devem ser utilizados posteriormente para alimentos ou ingredientes alimentares sem que sofram desinfecção.

\subsection{3- Remoção de matérias-primas impróprias:}

As matéria-primas que forem impróprias para o consumo humano devem ser isoladas durante os processos produtivos, de maneira a evitar a contaminação dos alimentos, das matérias-primas, da água e do meio ambiente.

4.5.4- Proteção contra a contaminação das matérias-primas e danos à saúde pública:

Devem ser utilizados controles adequados para evitar a contaminação química, física ou microbiológica, ou por outras substâncias indesejáveis. Também, devem ser tomadas medidas de controle com relação à prevenção de possíveis danos.

\section{6 - Armazenamento no local de produção:}

As matérias-primas devem ser armazenadas em condições cujo controle garanta a proteção contra a contaminação e reduzam ao mínimo as perdas da qualidade nutricional ou deteriorações.

\section{7- Transporte}

\subsection{1- Meios de transporte:}

Os meios de transporte de alimentos colhidos, transformados ou semi-processados dos locais de produção ou armazenamento devem ser adequados para o fim a que se destinam e constituídos de materiais que permitam o controle de conservação, da limpeza, desinfecção e desinfestação fácil e completa.

\subsection{2- Processos de manipulação:}

Devem ser de tal forma controlados que impeçam a contaminação dos materiais. Cuidados especiais devem ser tomados para evitar a putrefação, proteger contra a contaminação e minimizar danos. Equipamento especial, por exemplo, equipamento de refrigeração, dependendo da natureza do produto, ou das condições de transporte, (distância/tempo). No caso de utilizar gelo em contato com o produto deve-se observar a qualidade do mesmo conforme item 5.3.12.c) do presente regulamento.

\section{5 - CONDIÇÕES HIGIÊNICO-SANITÁRIAS DOS ESTABELECIMENTOS PRODUTORES/INDUSTRIALIZADORES DE ALIMENTOS}


OBJETIVO: Estabelecer os requisitos gerais/essenciais e de boas práticas de fabricação a que deve ajustar-se todo o estabelecimento com a finalidade de obter alimentos aptos para o consumo humano.

Requisitos Gerais para Estabelecimentos produtores/industrializadores de alimentos.

\section{1- Localização:}

Os estabelecimentos devem se situar em zonas isentas de odores indesejáveis, fumaça, pó e outros contaminantes e não devem estar expostos a inundações, quando não, devem estabelecer controles com o objetivo de evitar riscos de perigos, contaminação de alimentos e agravos à saúde.

\section{2- Vias de acesso interno:}

As vias e áreas utilizadas para circulação pelo estabelecimento, que se encontram dentro de seu perímetro de ação, devem ter uma superfície dura/ou pavimentada, adequada para o trânsito sobre rodas. Devem dispor de um escoamento adequado assim como controle de meios de limpeza.

\section{3- Edifícios e instalações:}

5.3.1- Para aprovação das plantas, os edifícios e instalações devem ter construção sólida e sanitariamente adequada . todos os materiais usados na construção e na manutenção não devem transmitir nenhuma substância indesejável ao alimento.

5.3.2- Deve ser levado em conta a existência de espaços suficientes para atender de maneira adequada, a toda as operações.

5.3.3- O desenho deve ser tal que permita uma limpeza adequada e permita a devida inspeção quanto a garantia da qualidade higiênico -sanitária do alimento.

5.3.4- Os edifícios e instalações devem impedir a entrada e o alojamento de insetos, roedores e ou pragas e também a entrada de contaminantes do meio, tais como: fumaça, pó, vapor, e outros.

5.3.5- Os edifícios e instalações devem ser projetados de forma a permitir a separação, por áreas, setores e outros meios eficazes, como definição de um fluxo de pessoas e alimentos, de forma a evitar as operações suscetíveis de causar contaminação cruzada.

5.3.6- Os edifícios e instalações devem ser projetados de maneira que seu fluxo de operações possa ser realizado nas condições higiênicas, desde a chegada da matéria-prima, durante 0 processo de produção, até a obtenção do produto final.

5.3.7- Nas áreas de manipulação de alimentos, os pisos devem ser de material resistente ao trânsito, impermeáveis, laváveis, e antiderrapantes; não possuir frestas e serem fáceis de limpar ou desinfetar. Os líquidos devem escorrer até os ralos (que devem ser do tipo sifão ou similar), impedindo a formação de poças. As paredes devem ser revestidas de materiais impermeáveis e laváveis, e de cores claras. Devem ser lisas e sem frestas e fáceis de limpar e desinfetar, até uma altura adequada para todas as operações. Os ângulos entre as paredes e o piso e entre as paredes e o teto devem ser abaulados hérméticos para facilitar a limpeza. Nas plantas deve-se indicar a altura da parede que será impermeável. O teto deve ser constituído e/ou acabado de modo a que se impeça o acúmulo de sujeira e se reduza ao mínimo a condensação e a formação de mofo, e deve ser fácil de limpar. As janelas e outras aberturas devem ser construídas de maneira a que se evite o acúmulo de sujeira e as que se comunicam com o exterior devem ser 
providas de proteção anti-pragas. As proteções devem ser de fácil limpeza e boa conservação. As portas devem ser de material não absorvente e de fácil limpeza. As escadas, elevadores de serviço, monta-cargas e estruturas auxiliares, como plataformas, escadas de mão rampas, devem estar localizadas e construidas de modo a não serem fontes de contaminação.

5.3.8- Nos locais de manipulação de alimentos, todas as estruturas e acessórios elevados devem ser instalados de maneira a evitar a contaminação direta ou indireta dos alimentos, da matériaprima e do material de embalagem, por gotejamento ou condensação e que não dificultem as operações de limpeza.

5.3.9- Os refeitórios, lavabos, vestiários e banheiro de limpeza do pessoal auxiliar do estabelecimento devem estar completamente separados dos locais de manipulação de alimentos e não devem ter acesso direto e nem comunicação com estes locais.

5.3.10- Os insumos, matérias-primas e produtos terminados devem estar localizados sobre estrados e separados das paredes para permitir a correta higienização do local.

5.3.11- Deve-se evitar a utilização de materiais que não possam ser higienizados ou desinfetados adequadamente, por exemplo, a madeira, a menos que a tecnologia utilizada faça seu uso imprescindível e que seu controle demonstre que não se constitui uma fonte de contaminação.

\subsubsection{2- Abastecimento de água:}

a. Dispor de um abundante abastecimento de água potável, que se ajuste ao item 8.3 do presente regulamento, com pressão adequada e temperatura conveniente, com um adequado sistema de distribuição e com proteção eficiente contra contaminação. No caso necessário de armazenamento, deve-se dispor ainda de instalações apropriadas e nas condições indicadas anteriormente. É imprescindível um controle freqüente da potabilidade da água.

b. O órgão competente poderá admitir variação das especificações químicas e físico-quimicas diferentes das normais quando a composição da água do local o fizer necessário e sempre que não se comprometa a sanidade do produto e a saúde pública.

c. O vapor e o gelo utilizados em contato direto com alimentos ou superfícies que entram em contato direto com os mesmos não devem conter nenhuma substância que possa ser perigosa para a saúde ou contaminar o alimento, obedecendo o padrão de água potável.

d. A água potável que seja utilizada para produção de vapor, refrigeração, para apagar incêndios e outros propósitos similares, não relacionados com alimentos, deve ser transportada por tubulações completamente separadas, de preferência identificadas através de cores, sem que haja nenhuma conexão transversal nem processo de retrosfriagem, com as tubulações que conduzem água potável.

\subsubsection{3- Efluentes e águas residuais:}

Eliminação de efluentes e águas residuais: os estabelecimentos devem dispor de um sistema eficaz de eliminação de efluentes e águas residuais, o qual deve ser mantido em bom estado de funcionamento. Todos os tubos de escoamento (incluídos o sistema de esgoto ) devem ser suficientemente grandes para suportar cargas máximas e devem ser construídos de modo a evitar a contaminação do abastecimento de água potável.

\subsubsection{4- Vestiários e banheiros:}

Todos os estabelecimentos devem dispor de vestiários, banheiros e quartos de limpeza adequados, convenientemente situados, garantindo a eliminação higiênica das águas residuais . 
Esses locais devem estar bem iluminados e ventilados, de acordo com a legislação, sem comunicação direta com o local onde são manipulados os alimentos . junto aos vasos sanitários e situados de tal modo que o pessoal tenha que passar junto a eles antes de voltar para área de manipulação, devem ser construídos lavabos com água fria ou fria e quente, providos de elementos adequados ( sabonete líquido, detergente, desinfetante, entre outros ) para lavagem das mãos em meios higiênicos convenientes para sua secagem. Não será permitido o uso de toalhas de pano. No caso de se usar toalhas de papel, deve haver um controle de qualidade higiênicosanitária e dispositivos de distribuição e lixeiras que não necessite de acionamento manual para essas toalhas . Devem ser indicado ao pessoal, a obrigatoriedade e a forma correta de lavar as mãos após o uso do sanitário.

\subsubsection{5- Instalações para lavagem das mãos nas áreas de produção:}

Devem ter instalações adequadas e convenientemente localizadas para lavagem e secagem das mãos sempre que a natureza das operações assim o exija. Nos casos em que sejam manipuladas substâncias contaminantes ou quando a natureza das tarefas requeira uma desinfecção adicionalà lavagem devem estar disponíveis também instalações para desinfeccção das mãos. Deve-se dispor de água fria ou fria e quente e de elementos adequados (sabonete líquido, detergente, desinfetante, entre outros) para limpeza das mãos. Deve haver também um meio higiênico adequado para secagem das mãos. Não é permitido o uso de toalhas de tecido. No caso de se usar toalhas de papel, deve haver um controle de qualidade higiênico-sanitária e dispositivos de distribuição e lixeiras que não necessite de acionamento manual para essas toalhas. As instalações devem estar providas de tubulações devidamente sifonadas que transportem as águas residuais até o local de deságue.

\subsubsection{6- Instalações para limpeza e desinfecção:}

Quando necessário, deve haver instalações adequadas para a limpeza e desinfeccção dos utensílios e equipamentos de trabalho, essas instalações devem ser construídas com materiais resistentes à corrosão, que possam ser limpados facilmente e devem estar providas de meios convenientes para abastecer de água fria ou fria e quente, em quantidade suficiente.

\subsubsection{7- lluminação e instalação elétrica:}

Os estabelecimentos devem ter iluminação natural ou não artificial que possibilitem a realização dos trabalhos e não comprometa a higiene dos alimentos. As fontes de luz artificial, de acordo com a legislação, que estejam suspensas ou colocadas diretamente no teto e que se localizem sobre a área de manipulação de alimentos, em qualquer das fases de produção, devem ser do tipo adequado e estar protegidas contra quebras . A iluminação não deverá alterar as cores. As instalações elétricas devem ser embutidas ou exteriores e, neste caso, estarem perfeitamente revestidas por tubulações isolantes e presas a paredes e tetos não sendo permitidas fiação elétrica solta sobre a zona de manipulação de alimento. O órgão competente poderá autorizar outra forma de instalação ou modificação das instalações aqui descritas, quando assim se justifique.

\subsubsection{8- Ventilação:}

O estabelecimento deve dispor de uma ventilação adequada de tal forma a evitar o calor excessivo, a condensação de vapor, o acúmulo de poeira, com a finalidade de eliminar o ar contaminado. A direção da corrente de ar nunca deve ir de um local sujo para um limpo. Deve haver abertura a ventilação provida de sistema de proteção para evitar a entrada de agentes contaminantes.

5.3.19- Armazenamento para lixos e materiais não comestíveis: 
O estabelecimento deve dispor de meios para armazenamento de lixos e materiais não comestíveis, antes da sua eliminação, do estabelecimento, de modo a impedir o ingresso de pragas e evitar a contaminação das matérias-primas, do alimento, da água potável, do equipamento e dos edifícios ou vias de acesso aos locais.

\subsubsection{0- Devolução de produtos:}

No caso de devolução de produtos os mesmos devem ser colocados em setor separado e destinados a tal fim por um período até que se determine seu destino.

\section{4- Equipamentos e utensílios}

\subsection{1-Materiais:}

Todo o equipamento e utensílio utilizado nos locais de manipulação de alimentos que possam entrar em contato com o alimento devem ser confeccionados de material que não transmitam substâncias tóxicas, odores e sabores que sejam não absorventes e resistentes à corrosão e capaz de resistir a repetidas operações de limpeza e desinfecção. As superfícies devem ser lisas e estarem isentas de rugosidade e frestas e outras imperfeições que possam comprometer a higiene dos alimentos ou sejam fontes de contaminação. Deve evitar-se o uso de madeira e de outros materiais que não possam ser limpos e desinfetados adequadamente, a menos que se tenha a certeza de que seu uso não será uma fonte de contaminação. Deve ser evitado o uso de diferentes materiais para evitar o aparecimento de corrosão por contato.

\subsection{2- Projetos e construção:}

a) Todos os equipamentos e utensílios devem ser desenhados e construídos de modo a assegurar a higiene e permitir uma fácil e completa limpeza e desinfecção e, quando possível, devem ser instalados de modo a permitir um acesso fácil e uma limpeza adequada, além disto devem ser utilizados exclusivamente para os fins a que foram projetados.

\section{6 - REQUISITOS DE HIGIENE DO ESTABELECIMENTO}

6.1- Conservação: Os edifícios, equipamentos, utensílios e todas as demais instalações, incluídos os desaguamentos, devem ser mantidos em bom estado de conservação e funcionamento. As salas devem ser secas, estar isentas de vapor, poeira, fumaça água residual.

\section{2 - Limpeza e desinfecção:}

6.2.1 - Todos os produtos de limpeza e desinfecção devem ser aprovados previamente para seu uso, através de controle da empres, identificados e guardados em local adequado, fora das áreas de manipulação dos alimentos. Além disto devem ser autorizados pelo órgão competente.

6.2.2 - Com a finalidade de impedir a contaminação dos alimentos, toda área de manipulação de alimentos, os equipamentos e utensílios devem ser limpos com a frequencia necessária e desinfetados sempre que as circunstâncias assim o exigem. O estabelecimento deve dispor de recipientes adequados, de forma a impedir qualquer possibilidade de contaminação, e em número e capacidade suficiente para verter os lixos e materiais não comestíveis.

6.2.3 - Devem ser tomadas precauções adequadas para impedir a contaminação dos alimentos quando as áreas, os equipamentos e os utensílios forem limpos ou desinfetados com águas ou detergentes ou com desinfetantes ou soluções destes. Os detergentes e desinfetantes devem ser adequados para esta finalidade e devem ser aprovados pelo órgão oficialmente competente. Os 
resíduos destes agentes que permaneçam em superfície suscetível de entrar em contato com alimento devem ser eliminados mediante uma lavagem cuidadosa com água potável antes que volte a ser utilizada para a manipulação de alimentos. Devem ser tomadas precauções adequadas na limpeza e desinfecção quando se realizem operações de manutenção geral ou particular em qualquer local do estabelecimento, equipamentos, utensílios ou qualquer elemento que possa contaminar o alimento.

6.2.4 - Imediatamente após o término do trabalho ou quantas vezes for conveniente, devem ser limpos cuidadosamente o chão incluindo o desague, as estruturas auxiliares e as paredes da área de manipulação de alimentos.

\subsection{5- Os vestiários devem estar sempre limpos.}

6.2.6 - As vias de acesso e os pátios situados nas imediações dos locais em que sejam parte destes devem manter-se limpos.

\section{3 - Programa de Controle de higiene e desinfecção:}

Cada estabelecimento deve assegurar sua limpeza e desinfecção. Não devem ser utilizados, nos procedimentos de higiene, substâncias odorizantes e/ou desodorantes em qualquer das suas formas nas áreas de manipulação dos alimentos, com vistas a evitar a contaminação pelos mesmos e que não se misturem os odores. O pessoal deve ter pleno conhecimento da importância da contaminação e de seus riscos, devendo estar bem capacitado em técnicas de limpeza.

\section{$6.4-$ Subprodutos:}

Os subprodutos armazenados de maneira que os subprodutos resultantes da elaboração que forem veículos de contaminação sejam retirados das áreas de trabalho tantas vezes quantas forem necessárias.

\section{5 - Manipulação, Armazenamento e Remoção de lixo :}

Deve manipular-se o lixo de maneira que se evite a contaminação dos alimentos e ou da água potável. Especial cuidado é necessário para impedir o acesso de vetores aos lixos. Os lixos devem ser retirados das áreas de trabalho, todas as vezes que sejam necessárias, no mínimo uma vez por dia. Imediatamente depois da remoção dos lixos, os recipientes utilizados para o seu armazenamento e todos os equipamentos que tenham entrado em contato com os lixos devem ser limpos e desinfetados. A área de armazenamento do lixo deve também ser limpa e desinfetada.

6.6 - Proibição de animais domésticos:

Deve-se impedir a entrada de animais em todos os lugares onde se encontram matérias-primas, material de embalagem, alimentos prontos ou em qualquer das etapas da produção/industrialização.

\section{7 - Sistema de Controle de Pagas:}

Deve-se aplicar um programa eficaz e contínuo de controle das pragas. Os estabelecimentos e as áreas circundantes devem manter inspeção periódica com vistas a diminuir consequentemente os riscos de contaminação.

No caso de invasão de pragas, os estabelecimentos devem adotar medidas para sua erradicação. As medidas de controle devem compreender o tratamento com agentes químicos, físicos ou 
biológicos autorizados. Aplicados sob a supervisão direta de profissional que conheça os riscos que o uso destes agentes possam acarretar para a saúde, especialmente os riscos que possam originar resíduos a serem retidos no produto. Só devem ser empregados praguicidas caso não se possa aplicar com eficácia outras medidas de prevenção. Antes da aplicação de praguicidas devese ter o cuidado de proteger todos os alimentos, equipamentos e utensílios da contaminação. Após a aplicação dos praguicidas deve-se limpar cuidadosamente o equipamento e os utensílios contaminados a fim de que antes de sua reutilização sejam eliminados os resíduos.

\title{
6.8 - Armazenamento de substâncias tóxicas:
}

Os praguicidas solventes e outras substâncias tóxicas que representam risco para a saúde devem ser rotulados com informações sobre sua toxidade e emprego . Estes produtos devem ser armazenados em áreas separadas ou armários fechados com chave, destinados exclusivamente com este fim, e só devem ser distribuídos ou manipulados por pessoal autorizado e devidamente capacitado sob controle de pessoal tecnicamente competente. Deve ser evitada a contaminação dos alimentos.

Não deve ser utilizado nem armazenado, na área de manipulação de alimentos, nenhuma substância que possa contaminar os alimentos, salvo sob controle, quando necessário para higienização ou sanitização.

\section{9 - Roupa e Objeto:}

Não devem ser guardados roupas nem objetos pessoais na área de manipulção de alimentos.

\section{7 - HIGIENE PESSOAL E REQUISITO SANITÁRIO}

\author{
7.1 - Capacitação em Higiene:
}

A direção do estabelecimento deve tomar providências para que todas as pessoas que manipulem alimentos recebam instrução adequada e contínua em matéria higiênica-sanitária, na manipulação dos alimentos e higiene pessoal, com vistas a adotar as precauções necessárias para evitar a contaminação dos alimentos. Tal capacitação deve abranger todas as partes pertinentes deste regulamento.

\section{2- Situação de saúde;}

A constatação ou suspeita de que o manipulador apresenta alguma enfermidade ou problema de saúde que possa resultar na transmissão de perigos aos alimentos ou mesmo que sejam portadores ou sãos, deve impedí-lo de entrar em qualquer área de manipulação ou operação com alimentos se existir a probabilidade da contaminação destes. Qualquer pessoa na situação acima deve comunicar imediatamente à direção do estabelecimento, de sua condição de saúde.

As pessoas que mantêm contatos com alimentos devem submeter-se aos exames médicos e laboratoriais que avaliem a sua condição de saúde antes do início de usa atividade e/ou periodicamente, após o início das mesmas. O exame médico e laboratorial dos manipuladores deve ser sxigido também em outras ocasiões em que houver indicação, por razões clínicas ou epidemiológicas.

\section{3 - Enfermidades contagiosas:}

A direção tomará as medidas necessárias para que não se permita a ningém que se saiba ou suspeite que padece ou é vetor de uma enfermidade suscetível de transmitir-se aos alimentos, ou 
que apresentem feridas infectadas, infecções cutâneas, chagas ou diarréias, trabalhar em qualquer área de manipulação de alimentos com microorganismos patógenos, até que obtenha alta médica. Toda pessoa que se encontre nestas condições deve comunicar imediatamente a direção do estabelecimento.

\section{4 - Feridas:}

Ninguém que apresente feridas pode manipular alimentos ou superfícies que entrem em contato com alimentos até que se determine sua reincorporação por determinação profissional.

\section{5- Lavagem das mãos:}

Toda pessoa que trabalhe numa área de manipulação de alimentos deve, enquanto em serviço, lavar as mãos de maneira freqüente e cuidadosa com um agente de limpeza autorizado e com água corrente potável fria ou fria e quente. Esta pessoa deve lavar as mãos antes do início dos trabalhos, imediatamente após o uso do sanitário, após a manipulação de material contaminado e todas as vezes que for necessário. Deve lavar e desinfetar as mãos imediatamente após a manipulação de qualquer material contaminante que possa transmitir doenças. Devem ser colocados avisos que indiquem a obigatoriedade e a forma correta de lavar as mãos. Deve ser realizado um controle adequado para garantir o cumprimento deste requisito.

\section{6 - Higiene pessoal:}

Toda pessoa que trabalhe em uma área de manipulação de alimentos deve manter uma higiene pessoal esmerada e deve usar roupa protetora, sapatos adequados, touca protetora. Todos estes elementos devem ser laváveis, a menos que sejam descartáveis e mantidos limpos, de acordo com a natureza do trabalho. Durante a manipulação de matérias-primas e alimentos, devem ser retirados todos os objetos de adorno pessoal.

\section{7 - Conduta pessoal:}

Nas áreas de manipulação de alimentos deve ser proibido todo o ato que possa originar uma contaminaçãod e alimentos, como: comer, fumar, tossir ou outras práticas anti-higiênicas.

7.8 - Luvas:

O emprego de luvas na manipulação de alimentos deve obedecer as perfeitas condições de higiene e limpeza destas. O uso de luvas não exime o manipulador da obrigação de lavar as mãos cuidadosamente.

7.9 - Visitantes:

Inclui-se nesta categoria todas as pessoas que não pertençam às áreas ou setores que manipulam alimentos. Os visitantes devem cumprir as disposições recomendadas nos itens 6.9, 7.3, 7.4 e 7.7 do presente regulamento.

7.10 - Supervisão: a responsabilidade do cumprimento dos requisitos descritos nos itens 7.1 à 7.9 deve recair ao supervisor competente.

\section{8 - REQUISITOS DE HIGIENE NA PRODUÇÃO}

8.1 - Requisitos aplicáveis à matéria-prima: 
8.1.1 - O estabelecimento não deve aceitar nenhuma matéria-prima ou insumo que contenha parasitas, microorganismos ou substâncias tóxicas, decompostas ou estranhas, que não possam ser reduzidas a níveis aceitáveis atravésd e processos normais de classificação e/ou preparação ou fabricação. O responsável técnico deve dispor de padrões de identidade e qualidade da matéria-prima ou insumos de forma a poder controlar os contaminantes passíveis de serem reduzidos a níveis aceitáveis, através dos processos normais de classificação e/ou preparação ou fabricação.

8.1.2 - O controle de qualidade da matéria-prima ou insumo deve incluir a sua inspeção, classificação, e se necessário análise laboratorial antes de serem levados à linha de fabricação. $\mathrm{Na}$ fabricação somente devem ser utilizadas matérias primas ou insumos em boas condições.

8.1.3 - As matérias-primas e os ingredientes armazenados nas áreas do estabelecimento devem ser mantidos em condições tais que evitem sua deterioração, protejam contra a contaminação e reduzam os danos ao mínimo possível. Deve-se assegurar, através do controle, a adequada rotatividade das matérias-primas e ingredientes.

\section{2 - Prevenção da contaminação cruzada:}

8.2.1- Devem ser tomadas medidas eficazes para evitar a contaminação do material alimentar por contato direto ou indireto com material contaminado que se encontrem nas fases iniciais do processo.

8.2.2- As pessoas que manipulam matérias-primas ou produtos semi elaborados com risco de contaminar o produto final enquanto não tenham retirado a roupa protetora que foi utilizada durante a manipulação de materias-primas e produtos semi elaborados, com os quais, tenham entrado em contato ou que tenha sido contaminada por matéria-prima ou produtos semi elaborados e, colocado outra roupa protetora limpa e cumprindo com os itens 7.5 e 7.6.

8.2.3 - Se existir possibilidade de contaminação, as mãos devem ser cuidadosamente lavadas entre uma e outra manipulação de produtos nas diversas fases do processo.

8.2.4 - Todo equipamento e utensílios que tenham entrado em contato com matérias-primas ou com material contaminado devem ser limpos e desinfetados cuidadosamente antes de serem utilizados para entrar em contato com produtos acabado.

\section{3 - Uso da água:}

8.3.1 - Como princípio geral na manipulação de alimentos somente deve ser utilizada água potável.

8.3.2 - Pode ser utilizada água não potável para a produção de vapor, sistema de refrigeração, controle de incêndio e outros fins análogos não relacionados com alimentos, com a aprovação do órgão competente.

8.3.3 - A água recirculada para ser reutilizada novamente dentro de um estabelecimento deve ser tratada e mantida em condições tais que seu uso não possa representar um risco para a saúde. 0 processo de tratamento deve ser mantido sob constante vigilância. Por outro lado, a água recirculada que não tenha recebido tratamento posterior pode ser utilizada nas condições em que o seu emprego não constitua um risco para saúde e nem contamine a matéria-prima nem o produto final. Deve haver um sistema separado de distribuição que possa ser identificado facilmente, para a utilização da água recirculada. Qualquer controle de tratamento para a utilização da água recirculada em qualquer processo de elaboração de alimentos deve ter sua eficácia comprovada e deve ter sido prevista nas boas práticas adotadas pelo estabelecimento e devidamente aprovadas 
pelo organismo oficialmente competente. As situações particulares indicadas nos itens 7.3.2 e neste devem estar em concordância com o item 5.3.2 e neste devem estar em concordância com o item 5.3.12.

\section{4-Produção:}

8.4.1 - A produção deve ser realizada por pessoal capacitado e supervisionada por pessoal tecnicamente competente.

8.4.2 - Todas as operações do processo de produção incluindo o acondicionamento, devem ser realizadas sem demoras inúteis e em condições que excluam toda a possibilidade de contaminação, deterioração e proliferação de microorganismos patogênicos e deteriorantes.

8.4.3 - Os recipientes devem ser tratados com o devido cuidado para evitar toda a possibilidade de contaminação do produto fabricado.

8.4.4 - Os métodos de conservação e os controles necessários devem ser tais que protejam contra a contaminação ou a presença de um risco à saúde pública e contra a deterioração dentro dos limites de uma prática comercial correta, de acordo com as boas práticas de prestação de serviço na comercialização.

$8.5-$ Embalagem

8.5.1 - Todo material utilizado para embalagem deve ser armazenado em condições higiênicosanitárias, em áreas destinadas para este fim. O material deve ser apropriado para o produto e as condições previstas de armazenamento e não deve transmitir ao produto substâncias indesejáveis que excedam os limites aceitáveis pelo órgão competente. O material de embalagemdeve ser seguro e conferir uma proteção apropriada contra a contaminação.

8.5.2 - As embalagens ou recipientes não devem ter sido anteriormente utilizados para nenhuma finalidade que possam dar lugar a uma contaminação do produto. As embalagens ou recipientes devem ser inspecionados imediatamente antes do uso, para verificar sua segurançae, em casos específicos, limpos e/ou desinfetados; quando lavados devem ser secos antes do uso. $\mathrm{Na}$ área de enchimento/embalagem, somente devem permanecer as embalagens ou recipientes necessários para uso imediato.

8.5.3 - a embalagem deve ser processada em condições que excluam as possibilidades a contaminação do produto.

\subsection{Responsabilidade Técnica e supervisão:}

O tipo de controle e supervisão necessário depende do risco de contaminação na produção do alimento. Os responsáveis técnicos devem ter conhecimento suficiente sobre as boas práticas de produçaõ de alimentos para poder avaliar e intervir nos possíveis riscos e assegurar uma vigilância e controle eficazes.

\section{7 - Documentação e registro:}

Em função do risco do alimento devem ser mantidos registros dos controles apropriados a produção e distribuição, conservando-os durante um período superior ao tempo de vida de prateleira do alimento.

8.8 - Armazenamento e transporte de matérias-primas e produtos acabados: 
8.8.1 - As matéria-primas e produtos acabados devem ser armazenadose transportados segundo as boas práticas respectivas de forma a impedir a contaminaçãoe/ou a proliferação de microorganismos e que protejam contra a alteração ou danos ao recipiente ou embalagem.

Durante o armazenamento deve ser exercida uma inspeção periódica dos produtos acabados, a fim de que somente sejam expedidos alimentos aptos para o consumo humano e sejam cumpridas as especificações de rótulo quanto as condições e transporte, quando existam.

8.2.2. - Os veículos de transportes pertencentes ao estabeleimento produtor de alimento ou por contratado devem atender as boas práticas de transporte de alimentos autorizados pelo órgão competente. Os veículos de transporte devem realizar as operações de carga e descarga fora dos locais de fabricação dos alimentos, devendo ser evitada a contaminação dos mesmos e do ar por gases de combustão. Os veículos destinados ao transporte de alimentos refrigerados ou congelados devem possuir instrumentos de controle que permitam verificar a umidade, caso seja necessário e a manutenção da temperatura adequada.

9 - Controle de alimentos

O responsável técnico deve usar metodologia apropriada de avaliação dos riscos de contaminação dos alimentos nas diversas etapas de produção contidas no presente regulamento e intervir sempre que necessário, com vistas a assegurar alimentos aptos ao consumo humano.

O estabelecimento deve prover instrumentos necessários para controles. 


\section{Anexo V}

\section{Equipamentos, Utensílios e a Legislação}

CENTRO DE VIGILÂNCIA SANITÁRIA - SÃO PAULO - Portaria CVS-6/99 10/03/99 Doesp 12/03/99 - Regulamento Técnico sobre os Parâmetros e Critérios para o controle Higiênico-Sanitário em Estabelecimentos de Alimentos

\section{Utensílios:}

Utensílios de mesa em qualidade igual ou maior que o número provável de consumidores, lavados manualmente ou à máquina. Utensílios de preparação suficientes, bem conservados, sem crostas, limpos e sem resíduos. Armazenados, após a lavagem e desinfecção, de forma ordenada e protegidos contra sujidades e insetos.

SECRETARIA DE VIGILÂNCIA SANITÁRIA DO MINISTÉRIO DA SAÚDE Portaria $n^{\circ} 326$ - SVS/MS de 30 de julho de 1997 - (DOU de 01/08/97)

\section{Instalações para Limpeza e Desinfecção:}

Quando necessário, deve haver instalações adequadas para a limpeza e desinfecção dos utensílios e equipamentos de trabalho. Essas instalações devem ser construídas com materiais resistentes à corrosão, que possam, ser limpos facilmente e devem estar providas de meios convenientes para abastecer de água fria ou quente, em quantidade suficiente.

Devem ser tomadas precauções adequadas para impedir a contaminação dos alimentos quando as áreas, os equipamentos e os utensílios forem limpos ou desinfetados com águas, detergentes, desinfetantes ou soluções destes. Os detergentes e desinfetantes devem ser adequados para esta finalidade e devem ser aprovados pelo órgão oficialmente competente. Os resíduos destes agentes que permaneçam em superfície suscetível de entrar em contato com alimento devem ser eliminados mediante uma lavagem cuidadosa com água potável antes que volte a ser utilizada para a manipulação de alimentos. Devem ser tomadas precauções adequadas na limpeza e desinfecção quando se realizem operações de manutenção geral ou particular em qualquer local do estabelecimento, equipamentos, utensílios ou qualquer local do estabelecimento, equipamentos, utensílios ou qualquer elemento que possa contaminar o alimento. 
